\title{
Highly Effective Adsorption Process of Ni(II) Ions with the Use of Sewage Sludge Fly Ash Generated by Circulating Fluidized Bed Combustion (CFBC) Technology
}

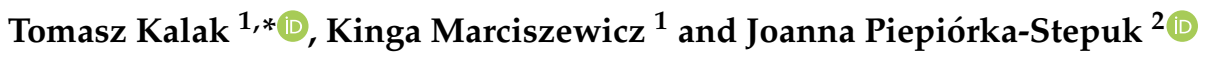 \\ 1 Department of Industrial Products and Packaging Quality, Institute of Quality Science, Poznań University of \\ Economics and Business, Niepodległości 10, 61-875 Poznań, Poland; kmarciszewicz@gmail.com \\ 2 Department of Mechanical Engineering, Division of Food Industry Processes and Facilities, Koszalin \\ University of Technology, Racławicka 15-17, 75-620 Koszalin, Poland; joanna.piepiorka@tu.koszalin.pl \\ * Correspondence: tomasz.kalak@ue.poznan.pl
}

check for

updates

Citation: Kalak, T.; Marciszewicz, K.; Piepiórka-Stepuk, J. Highly Effective Adsorption Process of Ni(II) Ions with the Use of Sewage Sludge Fly Ash Generated by Circulating Fluidized Bed Combustion (CFBC) Technology. Materials 2021, 14, 3106 https://doi.org/10.3390/ma14113106

Academic Editor: Katarzyna

Szewczuk-Karpisz

Received: 20 April 2021

Accepted: 2 June 2021

Published: 5 June 2021

Publisher's Note: MDPI stays neutral with regard to jurisdictional claims in published maps and institutional affiliations.

Copyright: (c) 2021 by the authors. Licensee MDPI, Basel, Switzerland. This article is an open access article distributed under the terms and conditions of the Creative Commons Attribution (CC BY) license (https:/ / creativecommons.org/licenses/by/ $4.0 /)$.

\begin{abstract}
Recently, more and more attention has been paid to the removal of nickel ions due to their negative effects on the environment and human health. In this research, fly ash obtained as a result of incineration of municipal sewage sludge with the use of circulating fluidized bed combustion (CFBC) technology was used to analyze the possibility of removing $\mathrm{Ni}$ (II) ions in adsorption processes. The properties of the material were determined using analytical methods, such as SEM-EDS, XRD, $\mathrm{BET}, \mathrm{BJH}$, thermogravimetry, zeta potential, SEM, and FT-IR. Several factors were analyzed, such as adsorbent dose, initial $\mathrm{pH}$, initial concentration, and contact time. As a result of the conducted research, the maximum sorption efficiency was obtained at the level of $99.9 \%$. The kinetics analysis and isotherms showed that the pseudo-second order equation model and the Freundlich isotherm model best suited this process. In conclusion, sewage sludge fly ash may be a suitable material for the effective removal of nickel from wastewater and the improvement of water quality. This research is in line with current trends in the concepts of circular economy and sustainable development.
\end{abstract}

Keywords: water quality; waste management; removal efficiency; sewage sludge fly ash; Ni(II) ions; kinetics

\section{Introduction}

The last decades of human activity have generated many environmental problems, such as water pollution (rivers, lakes, etc.), water waste, pollution of seas and oceans with industrial and consumer waste, and pollution with heavy metals and other toxic substances. The frequency of these phenomena is increasing, and despite taking many corrective and preventive measures, it still seems that the processes of environmental pollution are not stopping. It is necessary to take steps globally on many levels, from legal regulations to the appropriate, responsible attitude of every human being. Heavy metals are particularly dangerous to the environment and humans. They are not biodegradable, and they are able to accumulate in the ecosystem through the food chain and accumulate in living organisms. Even in low concentrations, they are carcinogenic, cause diseases of various systems and organs, and can also cause loss of life [1].

Nickel is one of toxic heavy metals that naturally occur in the environment and wastewaters. Nickel compounds are used in various industries (e.g., metal electroplating, silver refineries, storage battery industries, zinc base casting, etc.) that discharge their significant amounts into the environment in various forms, and their concentrations in industrial wastewater range from 3.40 to $900 \mathrm{mg} / \mathrm{L}$ [2]. The maximum nickel concentration limit in bottled water was set at $50 \mathrm{mg} / \mathrm{L}$ by the European Economic Community [3]. According to the United States Environmental Protection Agency (USEPA), Indian Standards Institution (ISI), and World Health Organization (WHO), the permissible limits of nickel 
in drinking water are $0.1,0.05$, and $0.02 \mathrm{mg} / \mathrm{L}$, respectively [4,5]. Nickel is one of the ubiquitous elements found in soil, water, atmospheric air, and the biosphere. Nickel enters into the soil via wind and during rainfall. Another source is the combustion of solid fuel (coal, oil) and waste, as well as industrial processes. An excessive amount of metal in plants may result in the appearance of phytotoxic symptoms, such as reduced photosynthesis, growth inhibition, and changes in enzyme activity. In addition, it can cause biochemical and physiological stress in plants, accompanied by the formation of hydrogen peroxide. This compound prevents the cells from working properly. Plant stress is a reaction to unfavorable environmental conditions. It is possible to develop a disease called chlorosis, during which the process of producing chlorophyll is disturbed, and diseased plants turn yellow. The growth of roots is inhibited, and they turn brown and thicken. In addition, nickel in green parts of plants disturbs the cation-anionic balance, which is responsible for good plant growth and development. In extreme conditions, it can cause plants to die [6].

Nickel exposure occurs mainly through the inhalation of dust and vapor particles. An excess of an element in the human body can accumulate in the lymph nodes, causing changes in the bone marrow and chromosomes. The high concentration of nickel sulphide they contain can cause serious damage to lungs and kidneys. On the other hand, prolonged exposure to dust in the worst cases leads to asthma, bronchitis, and pneumoconiosis. The most toxic nickel-containing compound is nickel carbonyl. Its excess in the human body can lead to pain, dizziness, insomnia, or vomiting. The respiratory system and most organs such as kidneys, liver, spleen, and brain are damaged. High levels of nickel in the human body can cause lung and bone cancer [7].

In everyday life, the widespread use of items containing nickel poses a great risk of contact allergy. This highly sensitizing metal can lead to irritation or contact eczema accompanied by burning and itchy skin. The metal is the most common allergen. Hypersensitivity can appear at any age. Everyday items are not the only source of allergies. Nickel found in food, tap water, and groundwater causes contact eczema and other chronic skin diseases (e.g., dermatopathy). The symptoms are very similar to those caused by food allergies [7].

Many advanced technologies are used to treat wastewater from heavy metals, such as ion exchange, ultrafiltration, reverse osmosis, chemical precipitation, electrolysis, and more $[8,9]$. Due to high material and operating costs, other alternative technologies are sought, as well as cheaper solutions and materials. These include adsorption processes, which have become more and more popular in recent years. They are characterized by low operating and equipment costs, ease of use, and the possibility of application to various types of contamination. The advantages include the possibility of using cheap industrial wastes as adsorbents, including fly ash obtained from the incineration of various wastes and materials, including municipal sewage sludge [10-14].

One of the most effective techniques for neutralizing municipal sewage sludge is thermal treatment, which brings many economic, energy, and environmental benefits and is recommended by European Union legislation. The quantity and quality of fly ash (FA) is dependent on the chemical composition of sludge, incineration, and exhaust gas treatment technologies [15]. The calorific value of average sewage sludge with $80 \%$ hydration is about $0.5 \mathrm{MJ} / \mathrm{kg}$. The calorific value of dust with a moisture content below $20 \%$ is between 12 and $18 \mathrm{MJ} / \mathrm{kg}$, and the bulk density is approx. $700 \mathrm{~kg} / \mathrm{m}^{3}$ [16]. In addition, this material is odorless, stable, safe in terms of sanitation, free from pathogenic organisms, non-biodegradable, and not harmful to human health and the environment. Fly ash resulting from fluidization combustion usually contains elements such as $\mathrm{Ca}, \mathrm{Cu}$, $\mathrm{Mg}, \mathrm{Mn}, \mathrm{K}, \mathrm{P}, \mathrm{Zn}, \mathrm{B}, \mathrm{Mo}$, and Fe, which are useful, for example, for plant growth. Fly ash can be a potential raw material for many industrial applications where there is a need for its binding properties and favorable chemical and physical properties. Important characteristics such as particle size, porosity, bulk density, water holding capacity, and surface area make FA suitable for the use as an adsorbent for many metal ions and organic and inorganic compounds. Some of the physicochemical properties of FA are changed 
as a result of frequent changes in the composition of municipal wastewater subjected to combustion processes. As a result, its industrial application may also change [17,18].

Most modern technologies of thermal treatment of municipal sewage sludge include circulating fluidized bed combustion (CFBC) technology. The main advantages of the technology are as follows: compatibility with many types of fuels, low emission of pollutants, high process efficiency, ease of maintenance, and the possibility of simultaneous combustion of dehydrated, dried, and fermented sludge. Many processes are involved in sewage sludge combustion, such as sewage sludge drying, combustion in the circulating fluidized bed furnace at a high temperature of $650{ }^{\circ} \mathrm{C}$ that produces waste gases and slag, cooling of gases, purification of gases in semi-dry and dry reactors using lime milk, active carbon, hydrated lime and ammonia, final purification of gases using bag filters, and the obtaining of fly ash.

About $20-25 \%$ of municipal solid waste produced in the European Union (EU) is treated by incineration. In 2020, the total amount of sewage sludge production was estimated at about 13 million tons, and there were 3664 large combustion plants in the EU (EU-28, including Great Britain before leaving the EU). Germany (1794.443 thousand tonnes in 2016), Spain (1174.4 thousand tonnes in 2016), France (1174 thousand tonnes in 2017), Poland (583.07 thousand tonnes in 2018), Turkey (318.503 thousand tonnes in 2018), and Romania (247.76 thousand tonnes in 2018) are the greatest producers of sewage sludge in the EU. The average mass of municipal solid waste incinerated is just under 200,000 tonnes per year. In Poland, there are several mono-incineration plants located in such cities as Warsaw, Kraków, Gdańsk, Gdynia, Bydgoszcz, Łódź, Olsztyn, Szczecin, Kielce, Łomża, and Zielona Góra [19-22].

This huge amount of produced sewage sludge should be disposed of, and an alternative may be incineration to reduce weight of waste and generate FA. One of the potential applications of FA from sewage sludge incineration may be in adsorption processes to remove metal ions from wastewater and to improve the purity of aquatic environment and water quality.

The goal of this investigation was to examine the adsorption process of $\mathrm{Ni}(\mathrm{II})$ ions in aqueous solutions using fly ash generated from the combustion of municipal sewage sludge in the circulating fluidized bed combustion (CFBC) technology under different conditions of initial and equilibrium $\mathrm{pH}$, adsorbent dosage, initial concentration, and contact time. Furthermore, the aim was to determine properties of the adsorbent material and to estimate the process kinetics, equilibrium, and isotherms.

\section{Experimental Procedure}

\subsection{Materials and Methods}

\subsubsection{Sewage Sludge Fly Ash Preparation}

The sewage sludge fly ash (SS-FA) used in these studies was generated in one of the plants located in Poland (Greater Poland voivodeship) in the process of burning municipal sewage sludge in the Sludge Thermal Transformation Installation using CFBC technology (Bydgoszcz, Poland). Four samples of fly ash were collected from different places in the ash container (silo) after all stages of purification processes in the CFBC installation, and next combined into one sample and mixed. Then fly ash was sieved to separate different grain fractions, and particles of less than $0.212 \mathrm{~mm}$ were used in the experiments. Samples were dried at $105^{\circ} \mathrm{C}$ to constant weight, and finally the moisture content was less than $0.2 \%$. In these studies, all chemicals were analytically pure, and distilled water was used.

\subsubsection{Sewage Sludge Fly Ash Characterization}

In the first stage, the sewage sludge fly ash (SS-FA) was analyzed for its physicochemical properties with the use of various techniques: bulk density, granulation analysis, SEM-EDS analysis, XRD, pore volume and specific surface area (BET, BJH), zeta potential, TGA analysis, SEM morphology, and FT-IR. The research methods and apparatus used were described in detail and included as Supplementary Material (Methods). 


\subsubsection{Nickel(II) Adsorption Process}

The adsorption experiments of $\mathrm{Ni}(\mathrm{II})$ ions in aqueous solutions were carried out at room temperature $\left(23 \pm 1{ }^{\circ} \mathrm{C}\right)$ and under normal pressure conditions. The solutions of $\mathrm{Ni}(\mathrm{II})$ (nickel standard for AAS in nitric acid $\left(\mathrm{HNO}_{3}\right)$, pure for analysis) were used. The SS-FA samples (weight from 2.5 to $500 \mathrm{mg} / \mathrm{L})$ and $\mathrm{Ni}\left(\mathrm{NO}_{3}\right)_{2}$ solution $(20 \mathrm{~mL}$, initial concentration $20-100 \mathrm{mg} / \mathrm{L}$ ) were mechanically shaken in conical flasks at $200 \mathrm{rpm}(1 \mathrm{~h})$. The $\mathrm{pH}$ of $\mathrm{Ni}(\mathrm{II})$ initial solutions was set with $0.1 \mathrm{M} \mathrm{NaOH}$ and $\mathrm{HNO}_{3}$. Subsequently, the SS-FA and solutions after adsorption processes were centrifuged at $4000 \mathrm{rpm}$ for phase separation. Next, the concentration of $\mathrm{Ni}(\mathrm{II})$ ions $(\mathrm{mg} / \mathrm{L})$ was determined with the use of SpectrAA 800 spectrophotometer (F-AAS, wavelength $\lambda=232 \mathrm{~nm}$ for nickel Ni, Varian, Palo Alto, USA). The measurements were repeated three times, and calculated arithmetic mean values were finally shown in the results.

The adsorption efficiency $A(\%)$ and adsorption capacity $q_{e}(\mathrm{mg} / \mathrm{g})$ were estimated based on Formulas (1) and (2), respectively:

$$
\begin{gathered}
A=\left[\frac{C_{0}-C_{e}}{C_{0}}\right] \times 100 \% \\
q_{e}=\frac{\left(C_{0}-C_{e}\right) \times V}{\mathrm{~m}}
\end{gathered}
$$

where $C_{0}$ and $C_{e}(\mathrm{mg} / \mathrm{L})$ are initial and equilibrium $\mathrm{Ni}(\mathrm{II})$ ion concentrations, respectively; $V(\mathrm{~L})$ - volume of solution, $\mathrm{m}(\mathrm{g})$ - mass of SS-FA.

Pseudo-first-order, pseudo-second-order kinetic models, and Langmuir and Freundlich adsorption models were estimated based on Formulas (3)-(6), respectively:

$$
\begin{gathered}
q_{t}=q_{e}\left(1-e^{k_{1} t}\right) \\
q_{t}=\frac{q_{e}^{2} k_{2} t}{1+q_{e} k_{2} t} \\
q_{e}=\frac{q_{\max } K_{L} C_{e}}{1+K_{L} C_{e}} \\
q_{e}=K_{F} C_{e}^{\frac{1}{n}}
\end{gathered}
$$

where $q_{e}(\mathrm{mg} / \mathrm{g})$ - the maximum amount of $\mathrm{Ni}(\mathrm{II})$ ions adsorbed per mass of SS-FA at equilibrium; $k_{1}(1 / \mathrm{min})$ - the rate constant of pseudo-first-order adsorption; $k_{2}(\mathrm{~g} /(\mathrm{mg} \cdot \mathrm{min})$.$) -$ the rate constant of pseudo-second-order adsorption, $K_{L}$-the Langmuir constant; $q_{\max }$ $(\mathrm{mg} / \mathrm{g})$ - the maximum adsorption capacity; $C_{e}(\mathrm{mg} / \mathrm{L})$ - the equilibrium concentration after the adsorption process; $1 / n$ - the intensity of adsorption; $K_{F}$-the Freundlich constant, $q_{t}(\mathrm{mg} / \mathrm{g})$ - the amount of $\mathrm{Ni}(\mathrm{II})$ ions adsorbed at any time $t(\mathrm{~min})$.

\section{Results and Discussion}

\subsection{Characterization of the SS-FA Adsorptive Material}

Fly ash resulting from the combustion of municipal sewage sludge was characterized by many methods. Firstly, the granulation analysis showed the following grain fractions: $<0.212 \mathrm{~mm}(90.75 \pm 1.3 \%), 0.212-0.5 \mathrm{~mm}(8.45 \pm 1.2 \%), 0.5-0.71 \mathrm{~mm}(0.49 \pm 0.07 \%)$, $0.71-1.0 \mathrm{~mm}(0.31 \pm 0.06 \%), 1.0-1.7 \mathrm{~mm}(0 \%),>1.7 \mathrm{~mm}(0 \%)$. Many researchers indicated in the literature that smaller FA particle sizes resulted in higher metal ion removal efficiency. This is due to the presence of larger specific surface area and the number of active centers capable of adsorbing metal ions [23]. Hence, following the literature analyses and research results, it can be concluded that it is appropriate to use SS-FA particles with the smallest particle size range to carry out $\mathrm{Ni}(\mathrm{II})$ adsorption experiments [24-27].

The SS-FA particles are irregular in shape and size, and often form various agglomerates, which affects the density of the bulk material. Therefore, bulk density of the SS-FA 
loose grains was first determined and was equal to $0.83 \pm 0.03 \mathrm{~g} / \mathrm{cm}^{3}$. Then, the material sample was compacted on a vibrating table, and the following density was obtained: $1.56 \pm 0.04 \mathrm{~g} / \mathrm{cm}^{3}$. Similar results were reported in the literature [28,29]. These analysis results may be relevant for the possible use of SS-FA as an additive to ceramic, construction, or building products.

X-ray diffraction analysis of SS-FA was carried out, and the spectrum is presented in Figure 1. The following chemical compounds have been shown to be the main crystalline phases of SS-FA: calcium sulfate $\left(\mathrm{CaSO}_{4}, 6 \%\right)$, maghemite $\left(\mathrm{synFe}_{2} \mathrm{O}_{3}, 6.38 \%\right)$, magnesium phosphate $\left(\mathrm{Zn}_{2} \mathrm{Mg}\left(\mathrm{PO}_{4}\right)_{2}, 6.75 \%\right)$, calcite $\left(\mathrm{CaCO}_{3}, 9.25 \%\right)$, portlandite $\left(\mathrm{Ca}(\mathrm{OH})_{2}, 11.4 \%\right)$, quartz (synSiO $\left.{ }_{2}, 13.16 \%\right)$, whitlockite (Ca $\left.2.59 \mathrm{MgO} 41\left(\mathrm{PO}_{4}\right)_{2}, 16.83 \%\right)$, and stanfieldite $\left(\mathrm{synMg}_{3} \mathrm{Ca}_{3}\left(\mathrm{PO}_{4}\right)_{4}, 30.23 \%\right)$. It should be noted here that SS-FA is a heterogeneous multicomponent product of the combustion process. Therefore, depending on the place of sampling in the silo tank, the quantitative compositions may slightly differ. However, $X$-ray diffraction analysis should reveal the same crystalline phases of the substances. Similar results of XRD analysis have been found in the literature [30-32].

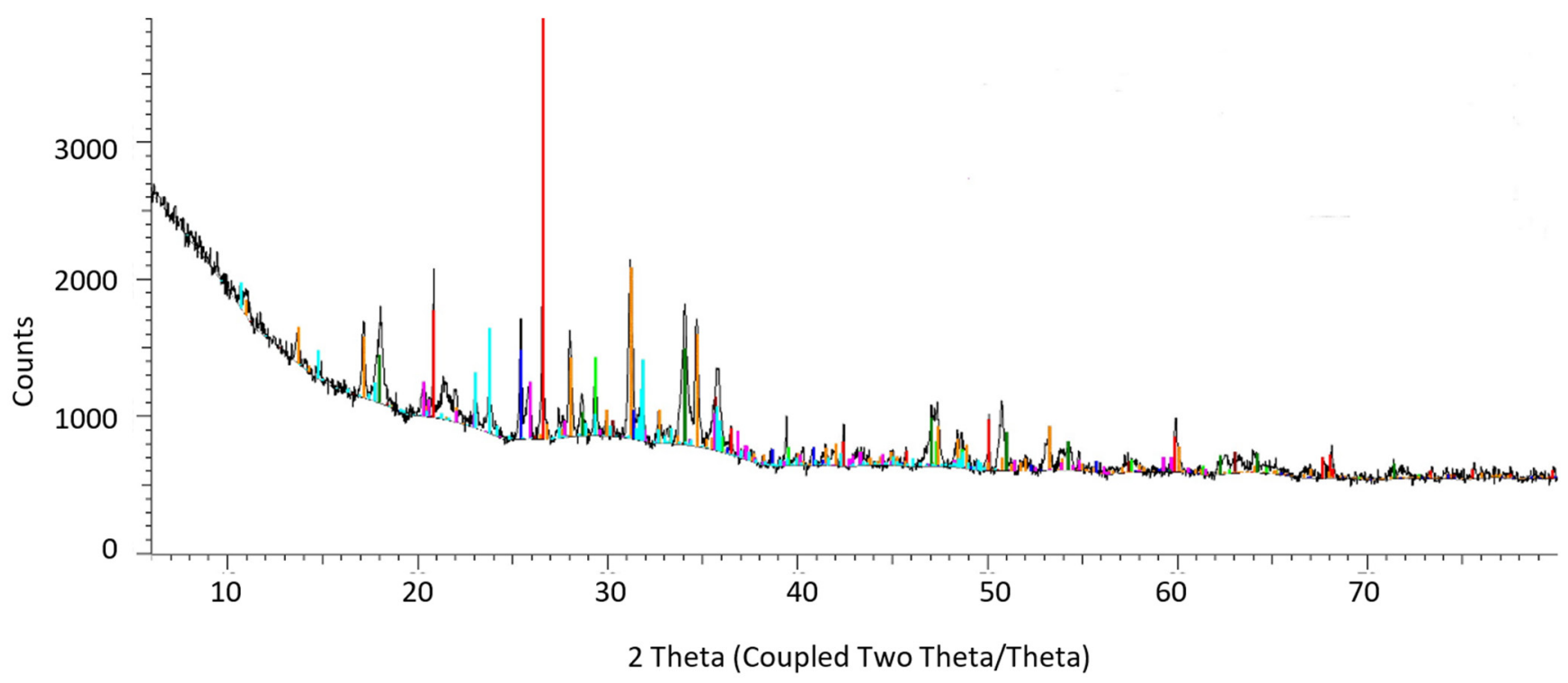

Figure 1. X-ray diffraction spectrum of SS-FA.

Measurements of particle size distribution were carried out, and the results are attached as Supplementary Material (Figure S1). It should be mentioned that during the analysis the larger and heavier SS-FA particles fell to the bottom of the suspension, and the apparatus measured the smaller and lighter particles that remained in suspension. Therefore, as a result of the measurement, one peak was observed with a particle size of $1205 \mathrm{~nm}$. Other authors obtained similar results on different fly ash samples [33,34]. According to the literature, smaller particles have the ability to dissolve or suspend in solutions more quickly and form a more stable suspension compared to larger ones. Additionally, smaller particles obtain higher adsorption in metal ion binding processes [24,35].

Thermogravimetric analysis was performed, and the results are presented in Figure 2. Generally speaking, a weight loss of the sample was observed with increasing temperature up to $1000{ }^{\circ} \mathrm{C}$. The TGA curve represents the change in weight loss, and the DTG curve represents a derivative weight loss $d w / d t(\mathrm{mg} / \mathrm{min})$ as a function of temperature. Initial weight loss up to $400{ }^{\circ} \mathrm{C}$ may be due to evaporation of moisture, volatile organic compounds, and removal of carbon monoxide. Significant weight loss was observed at $400-450{ }^{\circ} \mathrm{C}$ (an endothermic peak), which may result from the dehydroxylation reaction of calcium hydroxide [36,37]. A further increase in temperature causes another loss of SS-FA mass at $750{ }^{\circ} \mathrm{C}$. This phenomenon may be a consequence of the degradation of the grain wall surfaces caused by the release of gaseous products $\left(\mathrm{CO}_{2}\right)$ from their interior according 
to reaction Equation (7) $[35,38,39]$. Based on the literature, the presence of such $\mathrm{CaCO}_{3}$ polymorphs as aragonite, vaterite, and calcite can be assumed [40]. In these studies, the XRD analysis confirmed the presence of calcite $(9.25 \%)$. Other possible gases may be $\mathrm{CO}$, $\mathrm{H}_{2}$, and $\mathrm{CH}_{4}$ as a result of decomposition of fly ash particles [41].

$$
\mathrm{CaCO}_{3} \rightarrow \mathrm{CaO}+\mathrm{CO}_{2}
$$

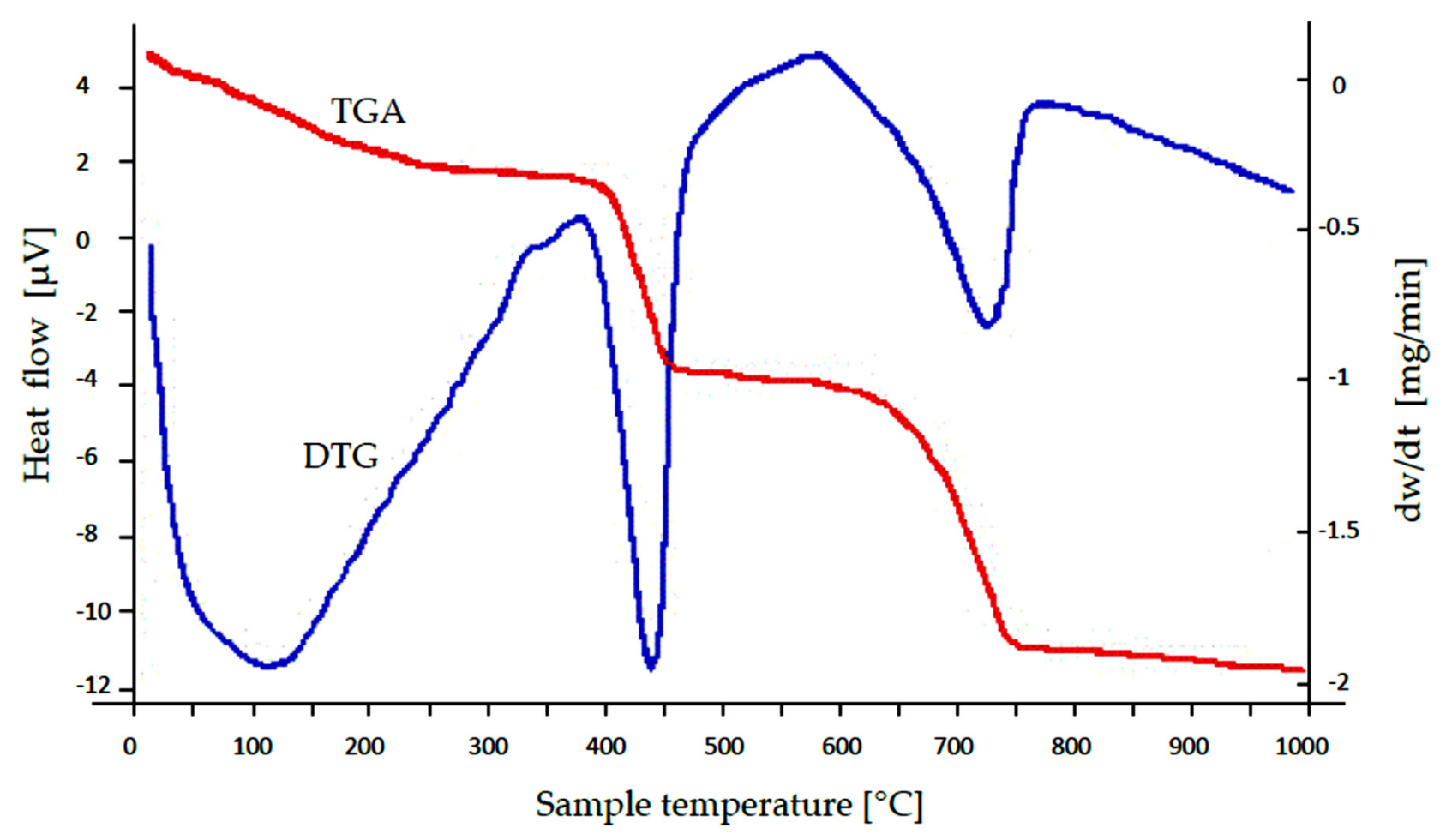

Figure 2. Thermogravimetric curves of SS-FA.

The analysis of the electrokinetic zeta potential was carried out on the SS-FA before and after rinsing with distilled water (Figure 3). The zeta potential is an important parameter in determining the stability of a solution and indicates the variability of surface potential for a specific material. It was found out that the surface charge of SS-FA varies with the $\mathrm{pH}$ of the solution and decreases from $21.2 \mathrm{mV}(\mathrm{pH} 2.6)$ to $1.3 \mathrm{mV}(\mathrm{pH} 4.3)$ and then increases to 9.3 ( $\mathrm{pH} 7$ ). In the range of $\mathrm{pH} 2.0-2.7$, low stability is a feature of this system. The charge does not reach the isoelectric point (IEP), which means that the surface charge was positive. This non-monotonic variation in fly ash as a function of $\mathrm{pH}$ is reported due to the possible dipolar interaction. An increase in $\mathrm{pH}$ can reduce the mobility of bridging protons, thus increasing the number of acid sites. This may be associated with the formation of Brønsted acid sites in aluminosilicates. Acid sites are formed with hydroxyl groups located between aluminum and silicon occupied by oxygen tetrahedra. The Si/Al ratio influences the acidity of aluminosilicates in such a way that the total number of acid sites increases as the $\mathrm{Si} / \mathrm{Al}$ ratio decreases. Replacing $\mathrm{Si}$ atoms with $\mathrm{Al}$ atoms in the material structure causes a loss of electric charge, which can be neutralized by the presence of an additional cation in the pore structure. Another explanation of non-monotonic behavior may also be due to morphological parameters such as size and shape of aggregates as well as chains formed in SS-FA particles. Additionally, the particle and pore size as well as $S_{B E T}$ value affect the amount of bound water with less activity acting as a solvent. In turn, water can affect the mobility of protons and the structure of the electrical double layer (EDL). The EDL should be different with the same surface structure in pores of the adsorbent and on its surface of micro- and nanoparticles. Parameters such as $\mathrm{pH}$, temperature, and solution composition can have impacts on the structure of the EDL on the particle surface and in 
pores of different sizes [42-47]. In the next step, the SS-FA was rinsed with distilled water in order to obtain a $\mathrm{pH}$ of 7 of the dispersion system. This procedure changed the value of the surface charge from positive $(16.0 \mathrm{mV}, \mathrm{pH} 2.2)$ to negative $(-11.2 \mathrm{mV}, \mathrm{pH} 7)$. The isoelectric point (IEP) was reached at $\mathrm{pH} 4.07$, which represents the achieved unstable suspension and equilibrium between negative and positive charges. At the IEP point, the SS-FA particles may have the lowest osmotic pressure, viscosity, and solubility.

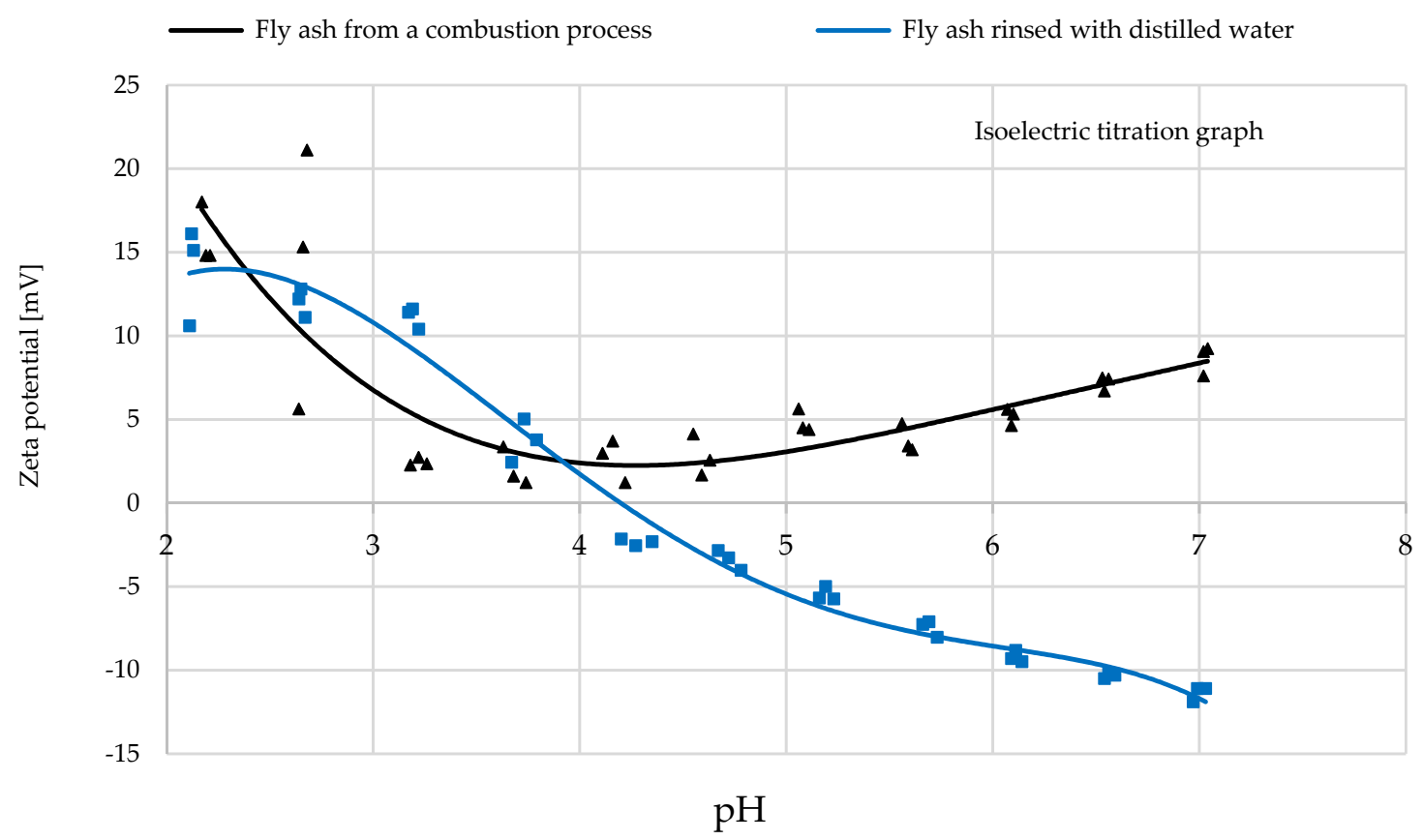

Figure 3. Plots of zeta potential vs. equilibrium $\mathrm{pH}$.

The SEM-EDS analysis was performed, and the results are presented in Figure 4 and Table 1. The plot shows the peaks corresponding to individual elements and oxides, the dominant of which were as follows: $\mathrm{O}, \mathrm{Ca}, \mathrm{P}, \mathrm{Al}, \mathrm{Si}, \mathrm{Fe}, \mathrm{Mg}$ and $\mathrm{P}_{2} \mathrm{O}_{5}, \mathrm{CaO}, \mathrm{Al}_{2} \mathrm{O}_{3}, \mathrm{SiO}_{2}$, $\mathrm{Fe}_{2} \mathrm{O}_{3}$, and $\mathrm{CO}_{2}$, respectively. Other elements and oxides were present in smaller amounts. Table 1 compares the elemental composition with other research results published in the literature. Similar content was observed for $\mathrm{Fe}_{2} \mathrm{O}_{3}, \mathrm{MnO}, \mathrm{Na}_{2} \mathrm{O}, \mathrm{K}_{2} \mathrm{O}$, and $\mathrm{TiO}_{2}$. The concentrations of other oxides $\left(\mathrm{CaO}, \mathrm{SiO}_{2}, \mathrm{P}_{2} \mathrm{O}_{5}, \mathrm{MgO}, \mathrm{Al}_{2} \mathrm{O}_{3}, \mathrm{SO}_{3}\right)$ were slightly different. Differences may be due to differences in chemical composition, different combustion parameters of the samples, or different analytical techniques.

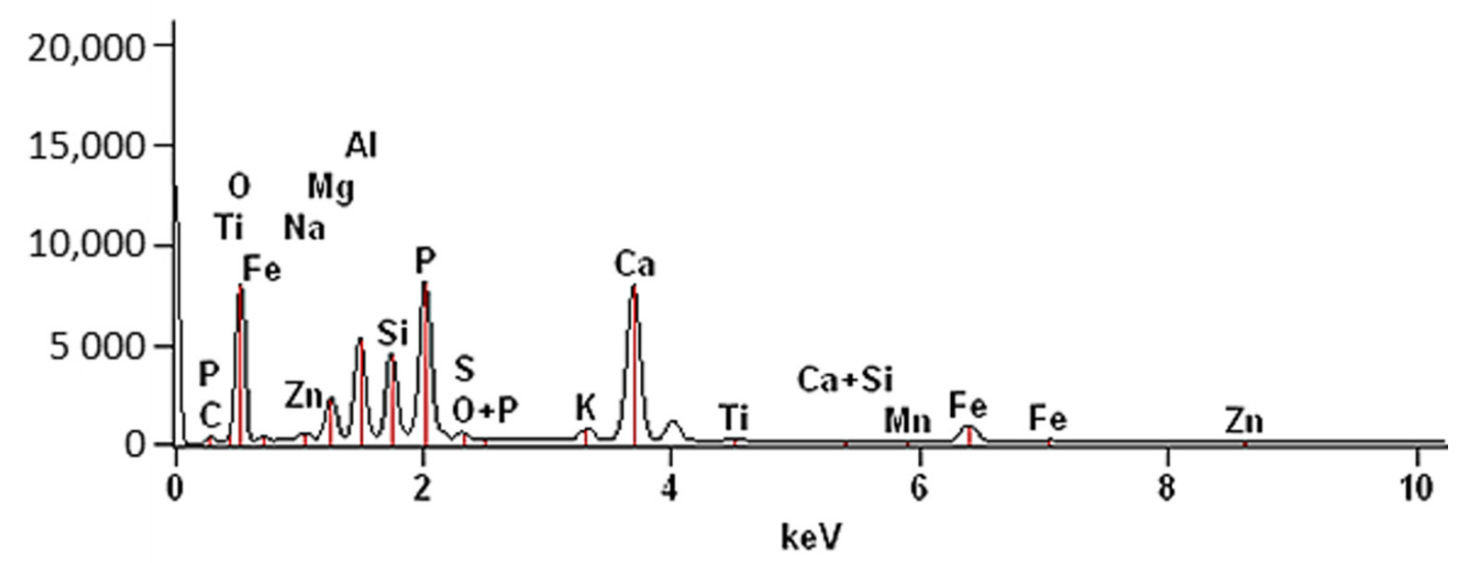

Figure 4. EDS spectrum of SS-FA (magn. x200). 
Table 1. Elemental composition of SS-FA (EDS microanalyzer) and comparison with the literature.

\begin{tabular}{|c|c|c|c|c|c|c|c|c|c|c|c|c|c|c|}
\hline Elements & $\mathrm{C}$ & $\mathbf{O}$ & $\mathrm{Na}$ & Mg & $\mathrm{Al}$ & Si & $\mathbf{P}$ & $S$ & K & $\mathrm{Ca}$ & $\mathrm{Ti}$ & Mn & $\mathrm{Fe}$ & $\mathrm{Zn}$ \\
\hline Weight (\%) & $\begin{array}{c}1.85 \pm \\
0.06\end{array}$ & $\begin{array}{l}44.79 \\
\pm 0.3\end{array}$ & $\begin{array}{c}0.54 \pm \\
0.03\end{array}$ & $\begin{array}{c}3.28 \pm \\
0.1\end{array}$ & $\begin{array}{c}6.41 \pm \\
0.3\end{array}$ & $\begin{array}{c}5.51 \pm \\
0.2\end{array}$ & $\begin{array}{l}11.35 \\
\pm 0.4\end{array}$ & $\begin{array}{c}0.41 \pm \\
0.09\end{array}$ & $\begin{array}{c}1.11 \pm \\
0.1\end{array}$ & $\begin{array}{l}17.68 \\
\pm 0.2\end{array}$ & $\begin{array}{c}0.54 \pm \\
0.03\end{array}$ & $\begin{array}{c}0.23 \pm \\
0.02\end{array}$ & $\begin{array}{c}5.43 \pm \\
0.3\end{array}$ & $\begin{array}{c}0.87 \pm \\
0.09\end{array}$ \\
\hline \multirow[t]{2}{*}{ Atomic (\%) } & $\begin{array}{c}3.41 \pm \\
0.2\end{array}$ & $\begin{array}{l}61.93 \\
\pm 0.6\end{array}$ & $\begin{array}{c}0.52 \pm \\
0.03\end{array}$ & $\begin{array}{c}2.99 \pm \\
0.09\end{array}$ & $\begin{array}{c}5.25 \pm \\
0.2\end{array}$ & $\begin{array}{c}4.34 \pm \\
0.3\end{array}$ & $\begin{array}{c}8.11 \pm \\
0.3\end{array}$ & $\begin{array}{c}0.28 \pm \\
0.03\end{array}$ & $\begin{array}{c}0.63 \pm \\
0.05\end{array}$ & $\begin{array}{c}9.76 \pm \\
0.5\end{array}$ & $\begin{array}{c}0.25 \pm \\
0.02\end{array}$ & $\begin{array}{c}0.09 \pm \\
0.01\end{array}$ & $\begin{array}{c}2.15 \pm \\
0.2\end{array}$ & $\begin{array}{c}0.29 \pm \\
0.02\end{array}$ \\
\hline & \multicolumn{14}{|c|}{ Content of oxides (wt. \%) } \\
\hline References & \multicolumn{2}{|c|}{$\mathrm{CO}_{2}$} & $\mathrm{Na}_{2} \mathrm{O}$ & $\mathrm{MgO}$ & $\mathrm{Al}_{2} \mathrm{O}_{3}$ & $\mathrm{SiO}_{2}$ & $\mathrm{P}_{2} \mathrm{O}_{5}$ & $\mathrm{SO}_{3}$ & $\mathrm{~K}_{2} \mathrm{O}$ & $\mathrm{CaO}$ & $\mathrm{TiO}_{2}$ & $\mathrm{MnO}$ & $\mathrm{Fe}_{2} \mathrm{O}_{3}$ & $\mathrm{ZnO}$ \\
\hline This research & \multicolumn{2}{|c|}{$6.97 \pm 0.3$} & $\begin{array}{c}0.73 \pm \\
0.04\end{array}$ & $\begin{array}{c}5.44 \pm \\
0.2\end{array}$ & $\begin{array}{l}12.11 \\
\pm 0.6\end{array}$ & $\begin{array}{l}11.78 \\
\pm 0.6\end{array}$ & $\begin{array}{l}26.02 \\
\pm 0.8\end{array}$ & $\begin{array}{c}1.02 \pm \\
0.1\end{array}$ & $\begin{array}{c}1.33 \pm \\
0.1\end{array}$ & $\begin{array}{l}24.74 \\
\pm 0.8\end{array}$ & $\begin{array}{c}0.89 \pm \\
0.03\end{array}$ & $\begin{array}{c}0.29 \pm \\
0.01\end{array}$ & $\begin{array}{c}7.77 \pm \\
0.3\end{array}$ & $\begin{array}{c}1.08 \pm \\
0.08\end{array}$ \\
\hline [48] & \multicolumn{2}{|c|}{-} & 0.37 & 1.4 & 27.0 & 48.8 & 1.2 & 0.22 & 0.85 & 6.2 & 1.3 & 0.15 & 10.2 & - \\
\hline [49] & \multicolumn{2}{|c|}{-} & 0.37 & 0.77 & 26.49 & 53.36 & 1.43 & 0.20 & 0.80 & 1.34 & 1.47 & - & 10.86 & - \\
\hline [50] & \multicolumn{2}{|c|}{-} & - & 0.97 & 22.03 & 57.25 & - & 0.76 & 0.52 & 2.97 & 0.68 & - & 8.36 & - \\
\hline [51] & \multicolumn{2}{|c|}{-} & 0.38 & 1.2 & 23.63 & - & 1.31 & 0.28 & 0.84 & 1.74 & 1.32 & 0.13 & 15.3 & - \\
\hline [52] & \multicolumn{2}{|c|}{-} & 0.42 & 0.78 & 23.59 & 52.11 & 1.31 & 0.49 & 0.80 & 2.61 & 0.88 & 0.03 & 7.39 & - \\
\hline [53] & \multicolumn{2}{|c|}{-} & 0.61 & 0.3 & 29.8 & 56.01 & 0.44 & - & 0.73 & 2.36 & 1.75 & - & 3.58 & - \\
\hline
\end{tabular}

As a result of BET analysis, adsorption and desorption surface parameters, including specific surface area $\left(S_{B E T}\right)$, pore volume of $0.114 \mathrm{~cm}^{3} / \mathrm{g}$, and average pore diameter $(A p d)$, were determined and are presented in Table 2 and Supplementary Material (Figures S2-S4). The shapes of the adsorption isotherms are characteristic of type III isotherms, which are convex towards the pressure axis. The type III isotherm refers to a situation where the adsorbed molecules occur at the most advantageous locations on the surface of a non-porous or macroporous adsorbent. This shape speaks to the so-called cooperative adsorption, which informs that previously adsorbed molecules increase the adsorption of other particles. In the case of low relative pressure, weak interactions between the adsorbate and the adsorbent cause adsorption with low efficiency. When the molecule is adsorbed once, the adsorbate-adsorbate interaction promotes the sorption of more molecules in the adsorption system, as a result of which the isotherm becomes convex towards the pressure axis [54].

Table 2. Adsorption and desorption surface parameters of SS-FA.

\begin{tabular}{cc}
\hline Parameters & Values \\
\hline BET adsorption cumulative surface area $\left(\mathrm{S}_{\mathrm{BET}}\right)\left(\mathrm{m}^{2} / \mathrm{g}\right)$ & 9.105 \\
BET desorption cumulative surface area $\left(\mathrm{S}_{\mathrm{BET}}\right)\left(\mathrm{m}^{2} / \mathrm{g}\right)$ & 12.368 \\
BJH adsorption cumulative volume of pores $(\mathrm{Vpa})\left(\mathrm{cm}^{3} / \mathrm{g}\right)$ & 0.032417 \\
BJH desorption cumulative volume of pores $(\mathrm{Vpd})\left(\mathrm{cm}^{3} / \mathrm{g}\right)$ & 0.03302 \\
BJH adsorption average pore diameter $($ Apda $)(\mathrm{nm})$ & 14.2408 \\
BJH desorption average pore diameter $(\mathrm{Apdd})(\mathrm{nm})$ & 10.6791 \\
\hline
\end{tabular}

The SEM analysis of SS-FA particles was performed using a scanning electron microscope, and the images are presented in Figure 5. As is seen, SS-FA is not homogeneous, and particles of different diameters and shapes are dominant. Larger particles have a more elongated, irregular shape with jagged ends. Smaller diameter particles are formed more regularly, more abundantly and have smooth tips. Spherical grains are also visible in the SS-FA. The surface of all particles is porous. Clear clusters of particles (lumps) appear in large numbers. Particle shape irregularities are the result of various parameters of the fluidizing combustion process, such as combustion duration and temperature. With the extension of the process, the obtained particles take on more spherical shapes or take a crystalline form. Similar observations could be observed in the literature [55-58]. According to the literature, the surface morphology and the specific surface area of FA particles affect the surface energy of the particles, which is responsible for the initiation of processes at the liquid-adsorbent interface. FA particles are characterized by higher surface energy and higher surface activity for a finer specific surface area. The ash porosity depends on the 
microporosity, the grain shape, and the extent of the grain distribution [57]. In the present study, based on the particle size distribution analysis, the SS-FA particle size was shown to be $1205 \mathrm{~nm}$, the BET adsorption specific surface area was $9.105 \mathrm{~m}^{2} / \mathrm{g}$, and the granulation analysis showed that the largest particle size was in the fraction with a particle size less than $0.212 \mu \mathrm{m}$.

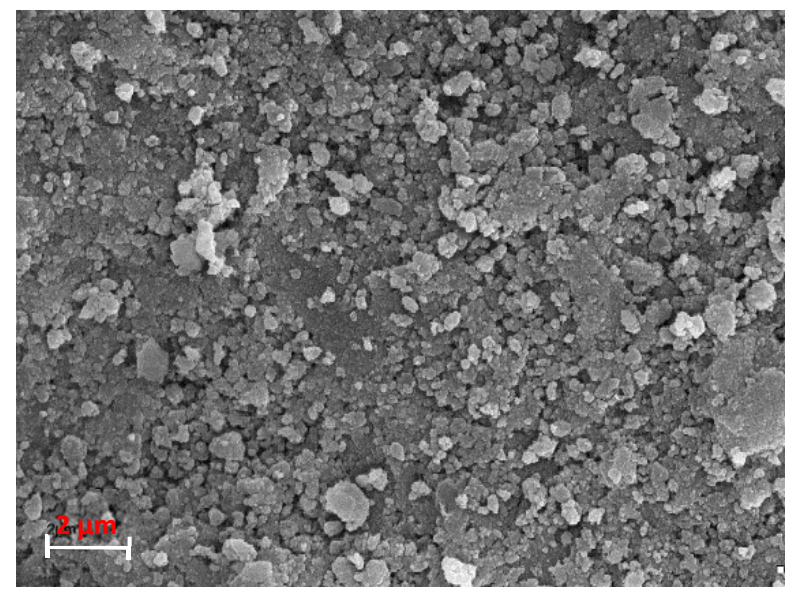

(a)

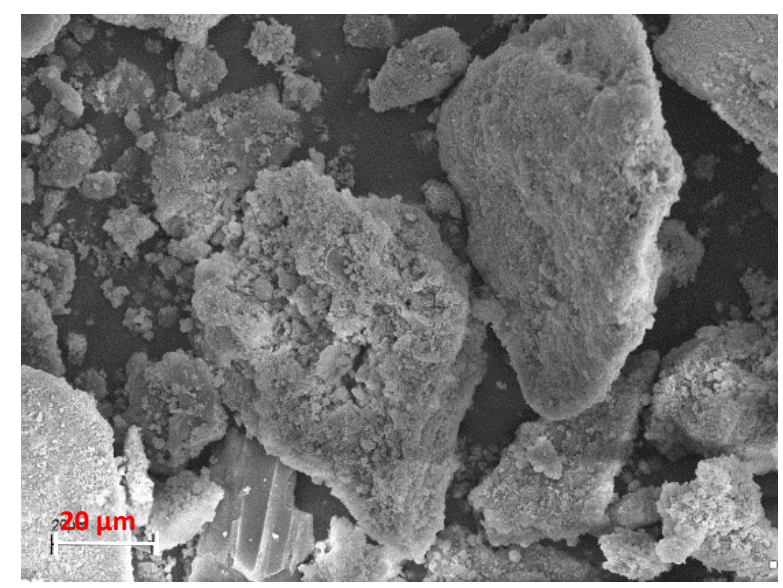

(b)

Figure 5. SEM images of SS-FA, scale bar: (a) $2 \mu \mathrm{m}$, (b) $20 \mu \mathrm{m}$.

\subsection{Adsorption Analysis of Ni(II) Ions}

3.2.1. Analysis of $\mathrm{pH}$ Profile

In the solution, $\mathrm{pH}$ parameter plays an important role in the adsorption process. Therefore, the influence of this factor on the efficiency of the process was investigated, and the results are presented in Figure $6 \mathrm{a}, \mathrm{b}$. The applied conditions of the experiments were as follows: the initial concentration of Ni(II) ions: $99.1 \mathrm{mg} / \mathrm{L}(\mathrm{pH} 2), 105 \mathrm{mg} / \mathrm{L}(\mathrm{pH} 3)$, $94.96 \mathrm{mg} / \mathrm{L}$ ( $\mathrm{pH} 4), 88.2 \mathrm{mg} / \mathrm{L}$ (pH 5), SS-FA dosage $0.3-50 \mathrm{~g} / \mathrm{L}, \mathrm{pH}$ range of 2-5, contact time $60 \mathrm{~min}$, rotation speed $200 \mathrm{rpm}, \mathrm{T}=23 \pm 1^{\circ} \mathrm{C}$. After analysis of the results, it was found out that the best performance was obtained at initial $\mathrm{pH} 4.0$ for the adsorbent doses of $10 \mathrm{~g} / \mathrm{L}(98.2 \%), 30 \mathrm{~g} / \mathrm{L}(99.89 \%), 50 \mathrm{~g} / \mathrm{L}(99.89 \%)$. In all cases an increase in adsorption was demonstrated. At initial $\mathrm{pH} 2.0$, the lowest efficiency was revealed from $0.25 \mathrm{~g} / \mathrm{L}$ up to $30.0 \mathrm{~g} / \mathrm{L}$, where $96.4 \%$ was achieved. To explain the effect of the initial $\mathrm{pH}$ of the solution on adsorption, the FA surface charge and the degree of its speciation can be taken into account. Most likely, the ion exchange mechanism was responsible for binding nickel ions. In Figure $7 \mathrm{a}, \mathrm{b}$, the relationship between equilibrium $\mathrm{pH}$ and removal efficiency and adsorption capacity is presented. As it is shown, any amount of SS-FA (from 0.3 to $50 \mathrm{~g} / \mathrm{L}$ ) increases $\mathrm{pH}$ up to 8.7, which is due to the alkaline nature of the adsorbent. Based on the XRD analysis, anions such as $\mathrm{SiO}_{3}{ }^{2-}, \mathrm{CO}_{3}{ }^{2-}, \mathrm{SO}_{4}{ }^{2-}, \mathrm{PO}_{4}{ }^{3-}$, and $\mathrm{OH}^{-}$were revealed in the adsorbent mass. At higher alkaline $\mathrm{pH}$, they could take part in the possible precipitation of Ni(II) ions. The SS-FA contained a lot of metal oxides, the electrostatic charge of which was affected by the $\mathrm{pH}$ of the solution. Hence, ion exchange and complexation processes, by binding with oxygen groups, could possibly occur. Equations (8)-(10) can represent possible general mechanism of the processes.

$$
\begin{gathered}
-\mathrm{XOH}+\mathrm{H}_{3} \mathrm{O}^{+} \rightarrow \mathrm{XOH}_{2}^{+}+\mathrm{H}_{2} \mathrm{O} \\
-\mathrm{XOH}+\mathrm{OH}^{-} \rightarrow \mathrm{XO}^{-}+\mathrm{H}_{2} \mathrm{O} \\
2\left(-\mathrm{XO}^{-}\right)+\mathrm{Ni}^{2+} \rightarrow(-\mathrm{XO})_{2} \mathrm{Ni}
\end{gathered}
$$

where $\mathrm{X}$ can represent $\mathrm{Ca}, \mathrm{Al}, \mathrm{K}, \mathrm{Si}$, etc. In these studies, no appropriate experiments were carried out to confirm the possible mechanisms $[13,59]$. 


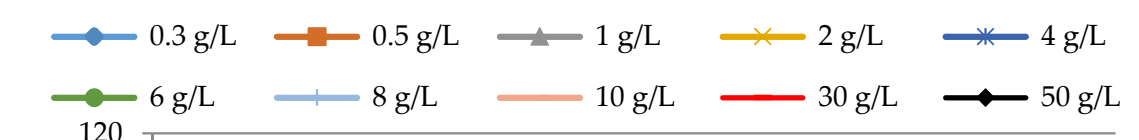

(a)
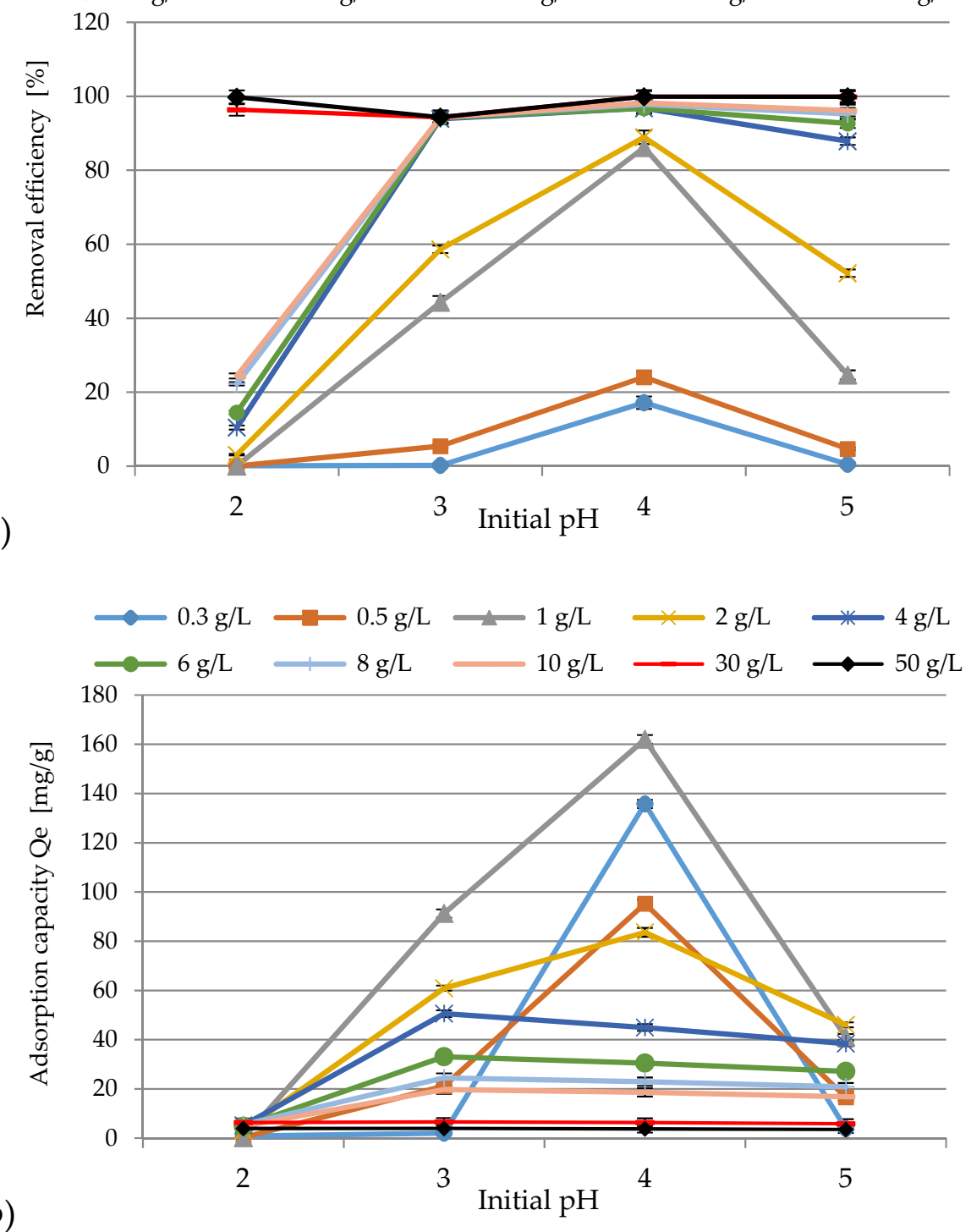

Figure 6. The effect of initial $\mathrm{pH}$ on removal efficiency (a) and adsorption capacity (b) of $\mathrm{Ni}$ (II) ions with SS-FA.

The surface of the SS-FA (hydrous oxide surface) was protonated by a significant amount of hydrogen ions ( $\mathrm{MOH}+\mathrm{H}^{+} \rightarrow \mathrm{M}(\mathrm{OH})_{2}{ }^{+}$), which resulted in an increase in the number of positively charged active centers and a decrease in the number of negatively charged centers. In an alkaline environment, hydrous oxides react with hydroxide ions to form deprotonated ions ( $\mathrm{MOH}+\mathrm{OH}^{-} \rightarrow \mathrm{MO}^{-}+\mathrm{H}_{2} \mathrm{O}$ ). In acidic solutions (initial $\mathrm{pH}<5$ ), nickel exists in the ionic form of $\mathrm{Ni}^{2+}$. Thus, it competes with $\mathrm{H}^{+}$ions, which, due to electrostatic repulsion, do not favor the adsorption of positively charged nickel ions. As a result, lower adsorption was observed. When the initial $\mathrm{pH}$ value was adjusted to $3-4$, the surface became more negatively electrostatically charged, ion exchange took place, and the appropriate groups were deprotonated, which made it possible to adsorb $\mathrm{Ni}^{2+}$ ions in greater amounts. The increase in adsorption with an increase in initial $\mathrm{pH}$ of the solution can also be explained by the presence of increased dissociation of surface hydroxyl groups from the SS-FA surface (at adsorbent dosages 30-50 g/L). At the same time, the formation of poorly soluble ions, such as $\mathrm{NiOH}^{+}$and $\mathrm{Ni}(\mathrm{OH})_{2}$ may partially contribute to the maximum removal of nickel ions. 


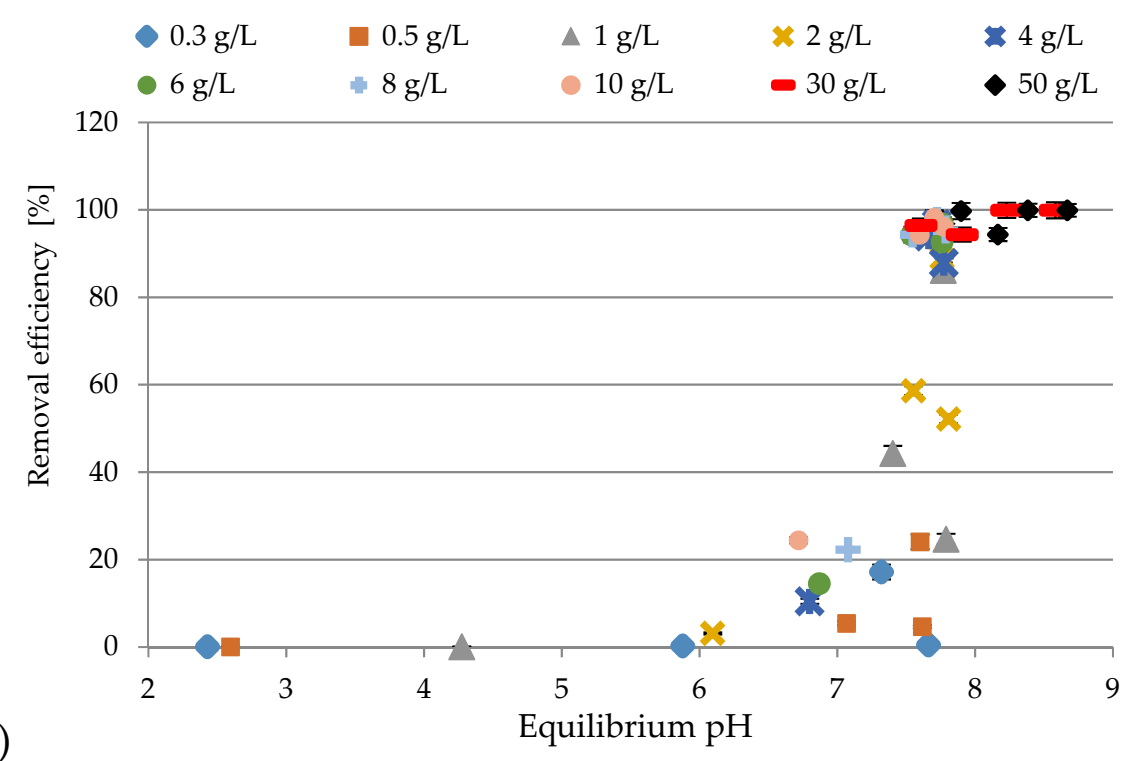

(a)

Equilibrium $\mathrm{pH}$

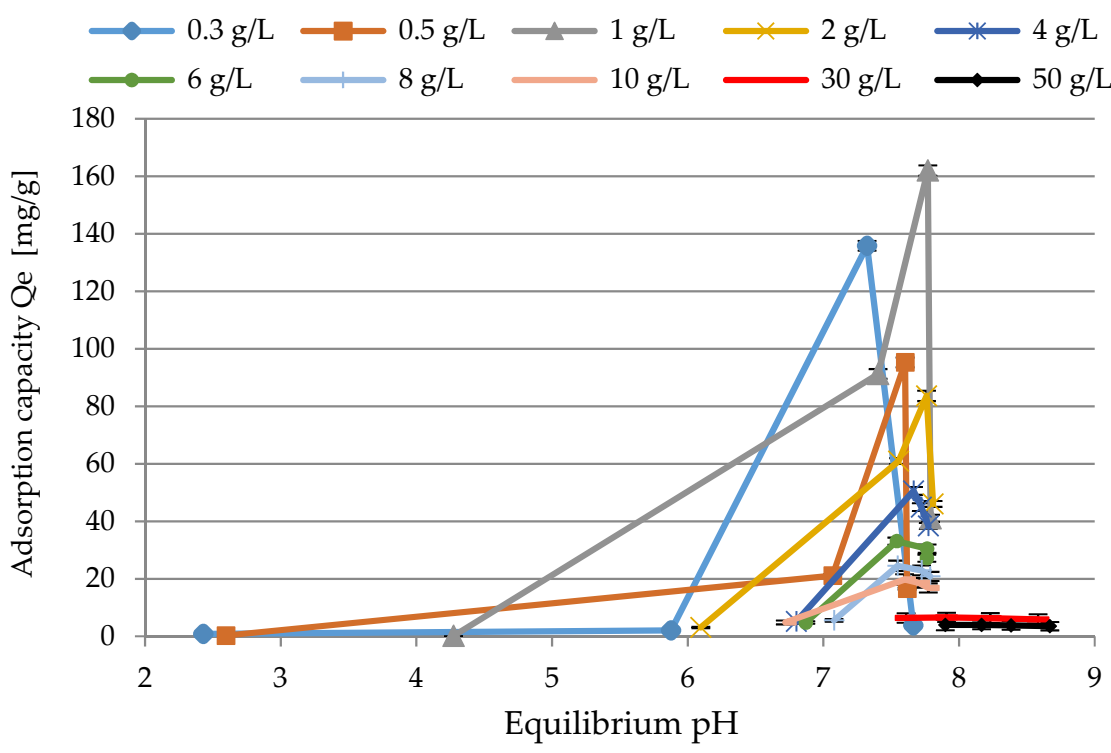

Figure 7. The relationship between equilibrium $\mathrm{pH}$ and removal efficiency (a) and adsorption capacity (b) of $\mathrm{Ni}(\mathrm{II})$ ions with SS-FA.

The zeta potential analysis revealed that the isoelectric point (IEP) was reached at an initial $\mathrm{pH}$ of 4.07. Above the value, the surface of fly ash seemed to be negatively charged. The adsorption experiments indicated that under optimal conditions at initial $\mathrm{pH} 4$, the adsorption efficiency was the highest. At initial $\mathrm{pH} 5$, the adsorption began to decrease. The phenomenon can be explained in this way: that repulsive electrostatic forces started to be dominant in the solution. Three different mechanisms can be proposed for the impact of the surface charge. At initial $\mathrm{pH}<5$, competitive adsorption of $\mathrm{Ni}^{2+}$ with $\mathrm{H}^{+}$and $\mathrm{H}_{3} \mathrm{O}^{+}$ ions on SS-FA surface probably occurred. At initial $\mathrm{pH}$ range 5-6, partial adsorption and surface precipitation of $\mathrm{NiO}$ and $\mathrm{Ni}(\mathrm{OH})_{2}$ took place. At initial $\mathrm{pH}>6$, precipitation of nickel hydroxides predominated. The neutral $\mathrm{NiO}$ and $\mathrm{Ni}(\mathrm{OH})_{2}$ particles were no longer attracted by the adsorbent particles, and electrostatic repulsive forces were acting [60,61].

\subsubsection{Effect of Adsorbent Dosage}

The effect of SS-FA dosage on the adsorption efficiency of $\mathrm{Ni}$ (II) ions was studied and the results are summarized in Figure 8a,b. The experiments were conducted under the 
following conditions: the initial concentration of $\mathrm{Ni}(\mathrm{II})$ ions: $99.1 \mathrm{mg} / \mathrm{L} \mathrm{(pH} \mathrm{2),} 105 \mathrm{mg} / \mathrm{L}$ ( $\mathrm{pH}$ 3), $94.96 \mathrm{mg} / \mathrm{L}$ ( $\mathrm{pH} 4), 88.2 \mathrm{mg} / \mathrm{L}$ ( $\mathrm{pH}$ 5), $\mathrm{pH}$ ranging from 2 to 5, rotation speed $200 \mathrm{rpm}, \mathrm{T}=23 \pm 1{ }^{\circ} \mathrm{C}$, contact time $60 \mathrm{~min}$, SS-FA dosage $0.25-50 \mathrm{~g} / \mathrm{L}$. Generally speaking, an increase in the removal efficiency with increasing dosage up to $50 \mathrm{~g} / \mathrm{L}$ was observed. As it is seen, the dose range of $4-50 \mathrm{~g} / \mathrm{L}$ could be considered optimal due to the highest efficiency in the tested $\mathrm{pH}$ range, and the maximum sorption results were as follows: 99.73\% ( $\mathrm{pH} 2,50 \mathrm{~g} / \mathrm{L}), 94.35 \%(\mathrm{pH} 3,50 \mathrm{~g} / \mathrm{L}), 99.89 \%(\mathrm{pH} 4,30-50 \mathrm{~g} / \mathrm{L})$, and $99.89 \%(\mathrm{pH} 5$, $50 \mathrm{~g} / \mathrm{L}$ ). It was not necessary to increase the amount of SS-FA, as no significant changes were observed in the adsorption process under the tested conditions. Moreover, a reduction in adsorption capacity was observed starting from $161.9 \mathrm{mg} / \mathrm{g}$ (dose $1 \mathrm{~g} / \mathrm{L}, \mathrm{pH}$ 4) and ending with $3.52 \mathrm{mg} / \mathrm{g}$ (dose $50 \mathrm{~g} / \mathrm{L}, \mathrm{pH}$ ). It was highly likely that active sites were fully occupied by $\mathrm{Ni}(\mathrm{II})$ ions when interacting with SS-FA adsorbent at their lower doses and were not fully utilized at higher doses. The decrease in sorption capacity is the result of an increase in the mass of the adsorbent, which resulted in an increase in the number of available metal ion binding sites.

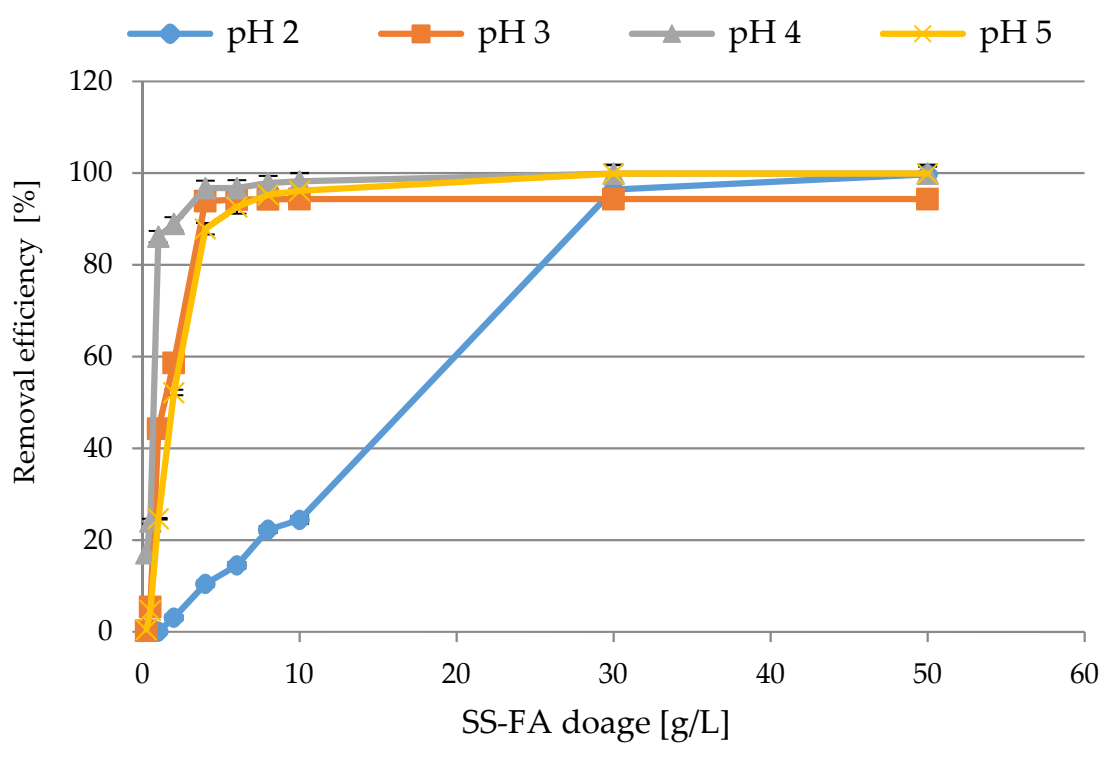

(a)

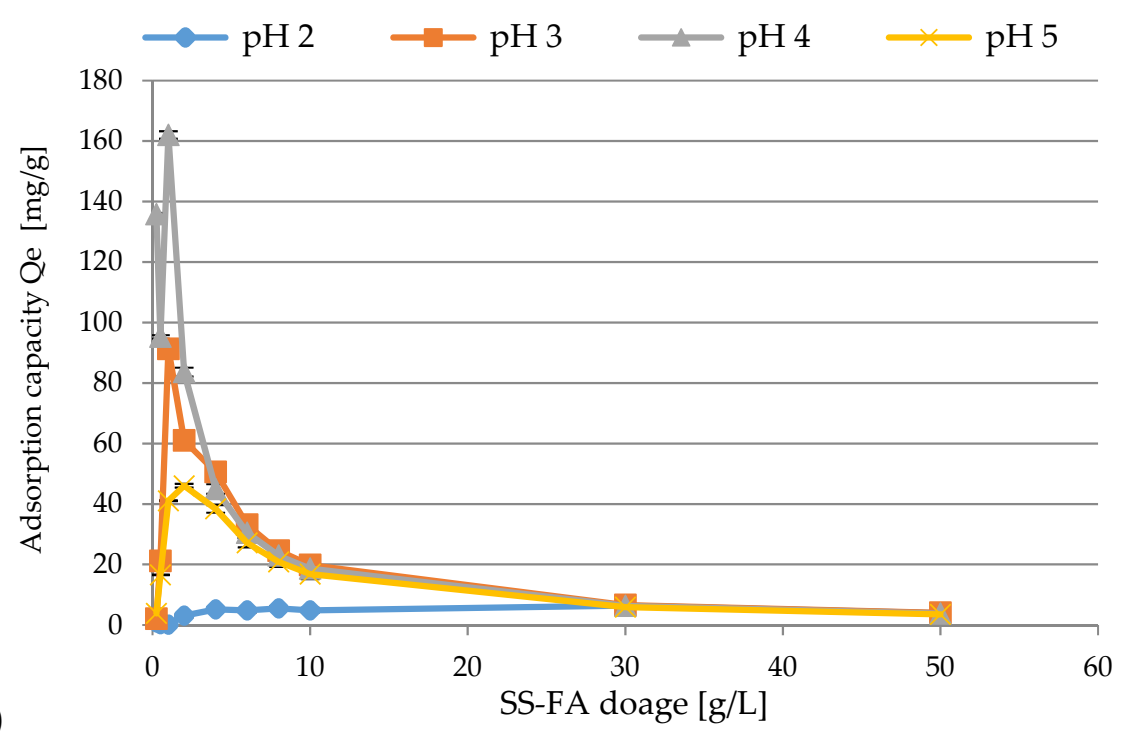

Figure 8. The effect of SS-FA dosage on adsorption efficiency (a) and adsorption capacity (b) of $\mathrm{Ni}(\mathrm{II})$ ions. 


\subsubsection{Effect of Initial Concentration of $\mathrm{Ni}$ (II) Ions}

Adsorption behavior under different initial concentration of $\mathrm{Ni}(\mathrm{II})$ ions was studied, and the results are presented in Figure 9. After analyzing the previous research results, it was decided to apply the following experimental conditions: initial concentration of $\mathrm{Ni}(\mathrm{II})$ ions (2.5-100 mg/L), adsorbent dosages $2.5-50 \mathrm{~g} / \mathrm{L}$, initial $\mathrm{pH}$ 4, contact time $60 \mathrm{~min}$, rotation speed $200 \mathrm{rpm}, \mathrm{T}=23 \pm 1{ }^{\circ} \mathrm{C}$. Generally speaking, an increase in adsorption efficiency was observed. The highest removal equal to $99.9 \%$ was achieved for the SS-FA dosage of $50 \mathrm{~g} / \mathrm{L}$ and initial concentrations of 50 and $100 \mathrm{mg} / \mathrm{L}$. Furthermore, a constant increase in the adsorption capacity ranging from the minimum values $(0.09-3.99 \mathrm{mg} / \mathrm{g})$ to the maximum value of $71.6 \mathrm{mg} / \mathrm{g}$ was observed.

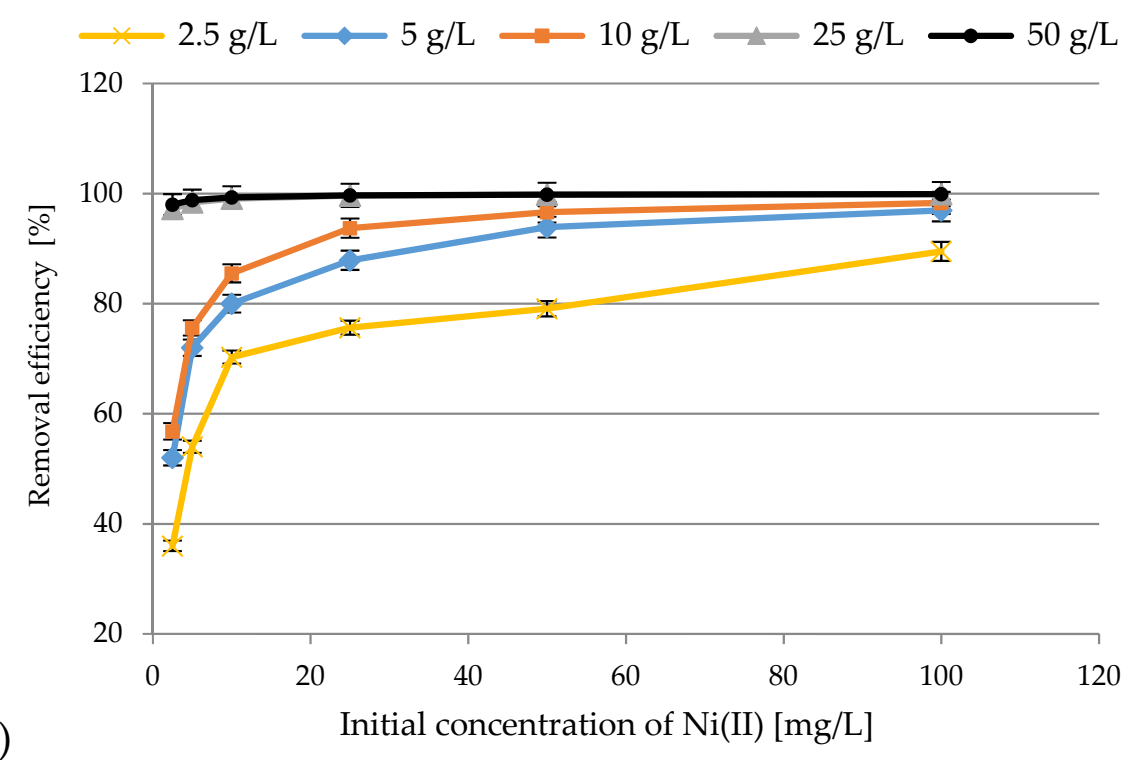

(a)
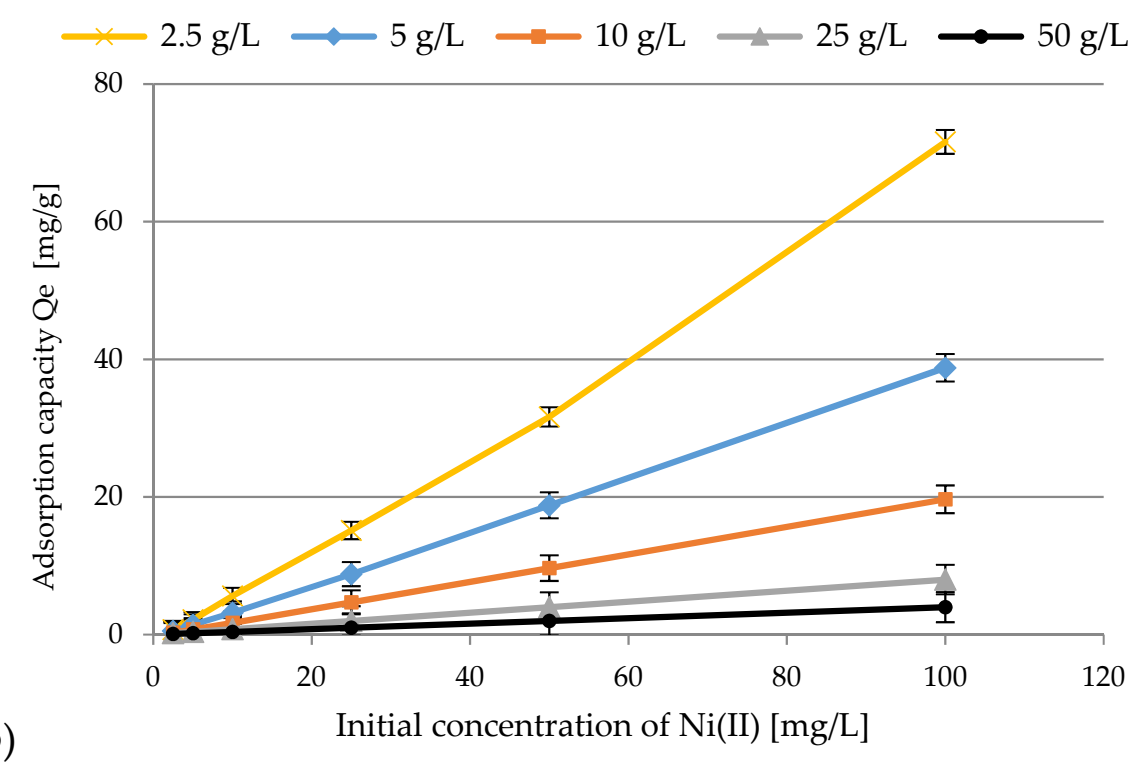

Figure 9. The effect of initial concentration of $\mathrm{Ni}(\mathrm{II})$ ions on SS-FA removal efficiency (a) and adsorption capacity (b).

Based on this analysis of the adsorption process, it was found out that the initial concentration of nickel ions influences the saturation of the SS-FA surface. As shown in Figure 9, the initial $\mathrm{Ni}$ (II) concentration was sufficient to initiate ion exchange at the interface between the aqueous and solid phase. Higher metal ion removal efficiency 
is proportional to greater driving force of mass transfer and lower resistance to metal sorption. Based on the literature, $\mathrm{Ni}$ (II) ions have an ionic radius equal to $70 \mathrm{pm}$. Many studies show that at the molecular level, the smaller the ionic radius of a metal, the greater its propensity to hydrolyze in aqueous solutions. Hydrolyzed molecules have a lower ability of adsorption, which translates into a decrease in the efficiency of the adsorption process $[13,62,63]$.

\subsubsection{Kinetics Analysis}

\section{Studies of Contact Time}

The influence of contact time on adsorption was investigated, and the results are presented in Figure 10. This parameter is important for the effective use of adsorbents in industry. Determination of the optimal contact time in the process can be successfully used to determine the amount of solutions in adsorption processes, to design them, and also to effectively reduce the costs of the process. Our previous research has helped to establish the following optimal experimental conditions: initial concentration of $\mathrm{Ni}(\mathrm{II}) 100 \mathrm{mg} / \mathrm{L}$, initial pH 4.0, SS-FA dosage $30 \mathrm{~g} / \mathrm{L}$, rotation speed $200 \mathrm{rpm}, \mathrm{T}=23 \pm 1{ }^{\circ} \mathrm{C}$. The maximum sorption $(99.71 \%$ ) was obtained within the first $30 \mathrm{~min}$ of the process, and there were no significant changes until $60 \mathrm{~min}$. The rapid initial increase in adsorption could have been caused by the use of optimal process conditions, but also by the high concentration of $\mathrm{Ni}(\mathrm{II})$ ions at the interface and the availability of more free active sites on the surface of the material. The mechanism of the ion exchange reaction can take many forms, but the equilibrium of the process was achieved gradually by the occupation of active centers by cations.

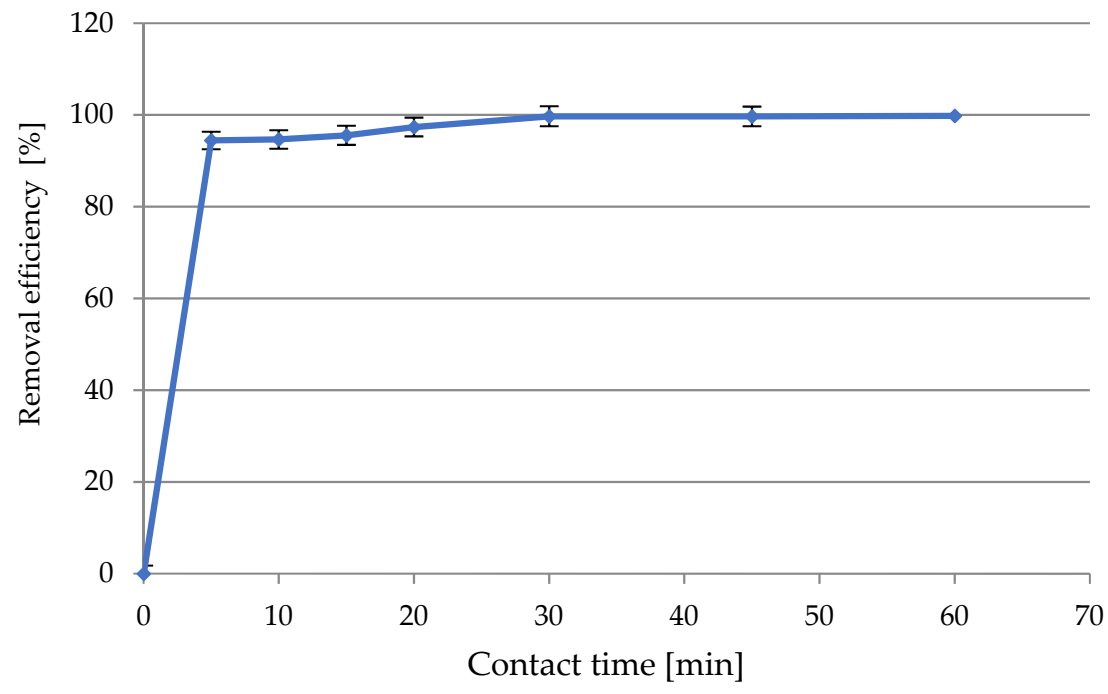

Figure 10. The effect of contact time on the Ni(II) ion removal efficiency.

\section{Pseudo-First-Order and Pseudo-Second-Order Kinetic Models}

Kinetics of the sorption of $\mathrm{Ni}$ (II) ions on the SS-FA was analyzed. Hence, pseudo-first order and pseudo-second order models were used (Figures 11 and 12), and the determined kinetic parameters are shown in Table 3. On the basis of the calculated values, it was found that a higher correlation coefficient $R^{2}$ was obtained for the pseudo-second-order model. Hence, the result suggests that this model is a better fit for the description of the kinetics of the adsorption process. This means a greater degree of correlation between the experimental $q_{e}$ and calculated $q_{t}$ values. Therefore, the sorption process took place by diffusion and could probably take the form of chemisorption. Nickel ions could form chemical bonds and have an affinity for active sites that increased their coordination number with the surface, as a result of which adhesion to the sorbent surface occurred. The research showed that the particles were less likely to collide with each other under the 
conditions of a lower concentration of nickel ions in the aqueous solution. An additional effect was faster binding of $\mathrm{Ni}(\mathrm{II})$ ions with active centers on the surface of the material.

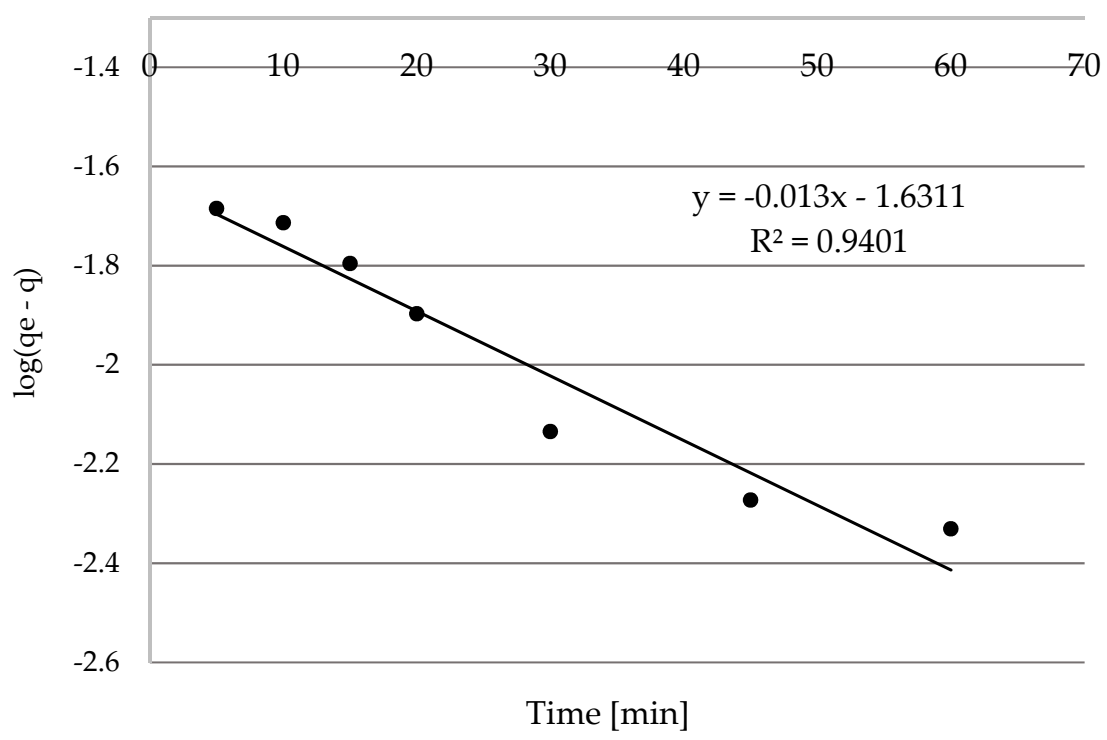

Figure 11. The pseudo first-order kinetic plot for the adsorption of Ni(II).

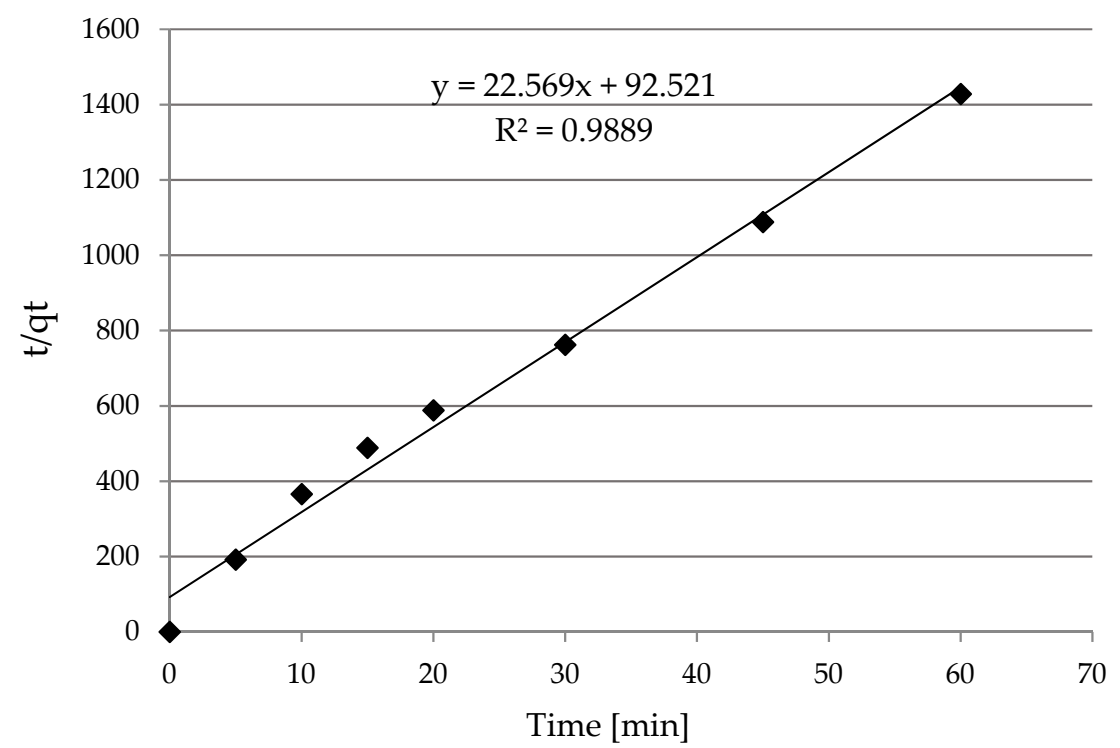

Figure 12. The pseudo second-order kinetic plot for the adsorption of Ni(II).

Table 3. Adsorption parameters of pseudo-first-order and the pseudo-second-order rate equations.

\begin{tabular}{|c|c|c|c|c|c|c|c|}
\hline \multirow[b]{2}{*}{ Metal Ion } & \multirow{2}{*}{$\begin{array}{c}\text { Adsorbent } \\
\text { Dosage }[\mathrm{g} / \mathrm{L}]\end{array}$} & \multicolumn{3}{|c|}{ Pseudo-First-Order Kinetic Model } & \multicolumn{3}{|c|}{ Pseudo-Second-Order Kinetic Model } \\
\hline & & $\begin{array}{c}k_{a d} \\
{\left[\mathrm{~min}^{-1}\right]}\end{array}$ & $\begin{array}{c}q_{e} \\
{[\mathrm{mg} / \mathrm{g}]}\end{array}$ & $R^{2}$ & $\begin{array}{c}k \\
\text { [g/mg min] }\end{array}$ & $\begin{array}{c}q_{e} \\
{[\mathrm{mg} / \mathrm{g}]}\end{array}$ & $R^{2}$ \\
\hline $\mathrm{Ni}(\mathrm{II})$ & 30 & 0.030 & 0.023 & 0.940 & 2441.91 & 0.044 & 0.989 \\
\hline
\end{tabular}

\subsubsection{Isothermal Analysis}

In these studies, the adsorption process was analyzed using Langmuir and Freundlich isotherms models, and the figures are presented in the Supplementary Material (Figures S5 and S6). Based on the calculated parameters, it was found that the adsorption data was better suited to the Freundlich model (Table 4). According to the equation, $K_{L}$ 
constant describes the spontaneity of adsorption and relates to the sorbent and binding energy of the solute. The spontaneity of the adsorption reaction increases proportionally with the increase in the $K_{L}$ value. This dependence translates into the presence of a more stable adsorbent and greater efficiency of the process. Nevertheless, the Freundlich isotherm describes the relationship between the concentration of metal ions dissolved in a liquid at equilibrium $(\mathrm{Ce})$ and the concentration of dissolved ions on the surface of an adsorbent (qe). A comparison of maximum adsorption capacity with other selected adsorbents is shown in Table 5.

Table 4. Isotherm model parameters for adsorption of Ni(II) using SS-FA.

\begin{tabular}{|c|c|c|c|c|c|c|c|}
\hline \multirow[b]{2}{*}{ Metal Ion } & \multirow{2}{*}{$\begin{array}{c}\text { Adsorbent } \\
\text { Dosage (g/L) }\end{array}$} & \multicolumn{3}{|c|}{ Langmuir Isotherm } & \multicolumn{3}{|c|}{ Freundlich Isotherm } \\
\hline & & $\begin{array}{c}\text { Calculated } \\
q_{m}(\mathrm{mg} / \mathrm{g})\end{array}$ & $K_{L}(\mathrm{~L} / \mathrm{mg})$ & $R^{2}$ & $\begin{array}{c}K_{f} \\
(\mathrm{mg} / \mathrm{g})(\mathrm{L} / \mathrm{mg})^{(1 / \mathrm{n})}\end{array}$ & $n$ & $R^{2}$ \\
\hline \multirow{5}{*}{$\mathrm{Ni}(\mathrm{II})$} & 2.5 & 94.72 & 0.0297 & 0.951 & 2.489 & 0.827 & 0.974 \\
\hline & 5 & 96.8 & 0.0208 & 0.946 & 1.954 & 0.745 & 0.958 \\
\hline & 10 & 81.81 & 0.034 & 0.977 & 3.152 & 0.869 & 0.980 \\
\hline & 25 & 126.32 & 0.1166 & 0.992 & 21.169 & 0.902 & 0.995 \\
\hline & 50 & 130.03 & 0.0435 & 0.983 & 11.242 & 0.820 & 0.984 \\
\hline
\end{tabular}

Table 5. Comparison of maximum adsorption capacity of SS-FA with different adsorbents.

\begin{tabular}{lcc}
\hline Adsorbents & Adsorption Capacity (mg/g) & Ref. \\
\hline Carbon nanotubes-granular activated carbon & 0.07 & {$[64]$} \\
(CNT-GAC) & 2.28 & {$[65]$} \\
Nano crystalline hydroxyapatite (nano HAp) & 10.8 & {$[66]$} \\
Graphene & 15 & {$[67]$} \\
LD slag & 17.86 & {$[68]$} \\
Multi-walled carbon nano tubes (MWCNT) & 46.55 & {$[66]$} \\
Graphene/MnO ${ }_{2}$ & 48 & {$[69]$} \\
Dolochar ash geopolymer & 49 & {$[70]$} \\
Pyrophyllite-based geopolymer & 62.51 & {$[71]$} \\
Hollow fibers & 72.04 & {$[72]$} \\
Graphene oxide/carboxy methyl cellulose & 83.33 & {$[73]$} \\
Nanostructured Al ${ }_{3}$ & 86.3 & {$[74]$} \\
Ion-imprinted polymer & 87 & {$[75]$} \\
MgO nanosheets (ultrasonic method) & 130 & {$[76]$} \\
Polyamidoxime chelating resin (PAO-AN) & 130.03 & This study \\
three dimensional & 178 & {$[77]$} \\
Sewage sludge fly ash (SS-FA) & 180.89 & {$[78]$} \\
Graphene oxide (GO) & 185.5 & {$[79]$} \\
Graphene oxide modified with & 188 & {$[80]$} \\
2,20-dipyridylamine (GO-DPA) & 225.6 & {$[81]$} \\
MgO nanosheets (precursor calcination) & 414 & {$[82]$} \\
Activated carbon derived from Xanthoceras & 520 & {$[83]$} \\
Polyvinyl alcohol/CNTs nanoporous & & \\
architectures (3DPCA) & & \\
Slag based geopolymer & & \\
Sieved geopolymer sample (SGS) & & \\
\hline
\end{tabular}

\subsection{FT-IR Studies}

The FT-IR analysis of SS-FA before and after the removal process was conducted, and the spectra are presented in Figure 13. To this purpose, the samples were analyzed under the following experimental conditions: SS-FA dose $30 \mathrm{~g} / \mathrm{L}$, initial concentration of $\mathrm{Ni}(\mathrm{II})$ ions $10 \mathrm{mg} / \mathrm{L}$, initial $\mathrm{pH} 4, \mathrm{~T}=23 \pm 1{ }^{\circ} \mathrm{C}$, contact time $60 \mathrm{~min}$. The explanation of the most essential FT-IR peaks is presented in Table 6 . The spectra were analyzed before and after the adsorption process in terms of differences in shape, intensity of bands, frequency, and possible interaction of functional groups with $\mathrm{Ni}(\mathrm{II})$ ions. Figure 13 shows that after the 
sorption process, the intensity of the bands shifted towards higher transmittance values, and their location remained at the same wavelengths or was slightly shifted. These changes can be identified as follows: 3278.88 (shift to $3279.15 \mathrm{~cm}^{-1}$ ), 1410.18 (shift to $1410.76 \mathrm{~cm}^{-1}$ ), 1026.64 (shift to $1025.89 \mathrm{~cm}^{-1}$ ), 873.87 (shift to $874.02 \mathrm{~cm}^{-1}$ ), 712.45 (shift to $712.8 \mathrm{~cm}^{-1}$ ), 595.08 (shift to $595.96 \mathrm{~cm}^{-1}$ ), 553.24 (shift to $555.27 \mathrm{~cm}^{-1}$ ). Bands at similar wavelengths are reported in the literature: bending $\mathrm{O}-\mathrm{Si}-\mathrm{O}\left(467 \mathrm{~cm}^{-1}\right.$, silica glass and quartz), symmetric stretching $\mathrm{Al}-\mathrm{Si}-\mathrm{O}\left(571 \mathrm{~cm}^{-1}\right)$, symmetric stretching $\mathrm{Si}-\mathrm{O}-\mathrm{Si}\left(796 \mathrm{~cm}^{-1}\right)$, asymmetric stretching Si-O $\left(1110 \mathrm{~cm}^{-1}, 1044 \mathrm{~cm}^{-1}\right)$ [84].

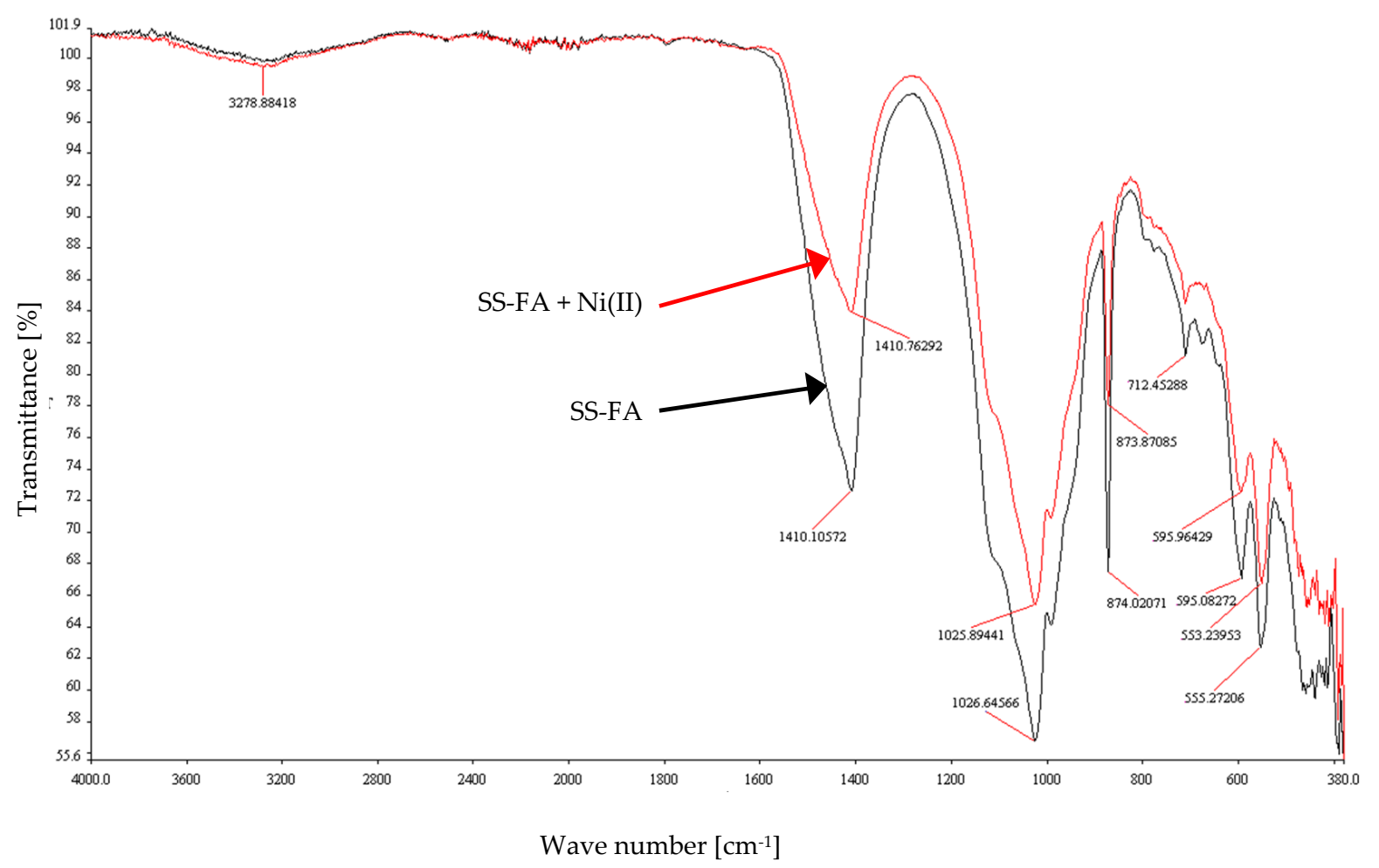

Figure 13. FT-IR spectrum of SS-FA before and after Ni(II) adsorption.

Table 6. FT-IR peaks of SS-FA.

\begin{tabular}{cc}
\hline FT-IR Band $\left.\mathbf{( c m}^{-\mathbf{1}}\right)$ & Assignment (Vibrations, Species) \\
\hline 3278.88 & stretching vibrations $\mathrm{O}-\mathrm{H}$ \\
$1410.76,1410.1$ & valence vibration of carbonate ions \\
$1025.89,1026.64$ & asymmetric stretching vibrations of silica $\mathrm{Si}-\mathrm{O}-\mathrm{Si}$ \\
$873.87,874.02$ & symmetric stretching of $\mathrm{Al}-\mathrm{O}-\mathrm{M}$, vibration of carbonates (calcite) \\
712.45 & symmetric stretching of $\mathrm{Si}-\mathrm{O}-\mathrm{Si}$ and $\mathrm{Al}-\mathrm{O}-\mathrm{Si}$ \\
$595.96,595.08$ & stretching vibrations $\mathrm{Al}-\mathrm{O}, \mathrm{Si}-\mathrm{O}-\mathrm{M}$ \\
$553.24,555.27$ & $\mathrm{O}-\mathrm{P}-\mathrm{O}, \mathrm{O}=\mathrm{P}-\mathrm{O}$ bending vibration (probably $\left.\mathrm{P}_{2} \mathrm{O}_{5}\right)$ \\
$380-440$ & bond bending vibrations Si-O-Si \\
\hline
\end{tabular}

\section{Conclusions}

Fly ash generated from the combustion of municipal sewage sludge in the circulating fluidized bed combustion (CFBC) technology was examined for the possibility of removing $\mathrm{Ni}(\mathrm{II})$ ions from aqueous solutions. The selected analytical methods were used to evaluate the physicochemical properties of the material. The efficiency of the adsorption process depends on such parameters as the dose of the sorbent, initial $\mathrm{pH}$, initial concentration, and contact time; therefore, the influence of these parameters on the process was analyzed in subsequent experiments. The conducted research showed that the maximum adsorption efficiency was $99.9 \%$ under the following conditions: initial $\mathrm{pH}$ 4.0, SS-FA dosage 
$50 \mathrm{~g} / \mathrm{L}$, initial concentration range $94.9 \mathrm{~g} / \mathrm{L}$, contact time $60 \mathrm{~min}$, rotation speed $200 \mathrm{rpm}$, $\mathrm{T}=23 \pm 1{ }^{\circ} \mathrm{C}$. Overall, however, it can be seen that the process yield was above $90 \%$ under many experimental conditions. The SS-FA material was characterized before and after adsorption by FT-IR analysis. Changes in intensity of bands and slight shifts of the peaks were observed. Additionally, the kinetics of the process was analyzed, and isotherms were determined. The analysis showed that the performed adsorption process is best described by the pseudo-second order kinetic model and the Freundlich model. The maximum adsorption capacity $q_{\max }$ calculated on the basis of the Langmuir equation was $130.03 \mathrm{mg} / \mathrm{g}$ for an SS-FA dosage of $50 \mathrm{~g} / \mathrm{L}$.

In conclusion, as a result of the research, it was unequivocally found that postproduction SS-FA waste is capable of removing $\mathrm{Ni}(\mathrm{II})$ ions with a very high process efficiency due to the content of appropriate functional groups in the material composition and favorable physicochemical properties. Promising research results are worth continuing experiments on the adsorption of other heavy metal ions. Most importantly, an essential conclusion is the real possibility of industrial use of SS-FA in order to improve water quality by removing heavy metal ions, which is in line with current global trends in sustainable development, circular economy, and climate neutrality.

Supplementary Materials: The following are available online at https:/ /www.mdpi.com/article/10

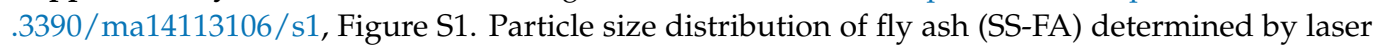
diffraction; Figure S2. The low temperature BET adsorption and desorption isotherm; Figure S3. Linear form of BET adsorption isotherm; Figure S4. Pore volume distribution (the BJH method); Figure S5. Langmuir isotherms for adsorption of Ni(II) ions with SS-FA; Figure S6. Freundlich isotherms for adsorption of $\mathrm{Ni}(\mathrm{II})$ ions with SS-FA.

Author Contributions: Conceptualization, T.K.; methodology, T.K.; validation, T.K.; formal analysis, T.K.; investigation, T.K. and K.M.; resources, T.K. and J.P.-S.; data curation, T.K.; writing—original draft preparation, T.K.; writing—review and editing, T.K. and J.P.-S.; visualization, T.K.; supervision, T.K.; project administration, T.K.; funding acquisition, T.K. and J.P.-S. All authors have read and agreed to the published version of the manuscript.

Funding: This research did not receive a specific grant from any a funding agency in the public, commercial, or not-for-profit sectors.

Institutional Review Board Statement: Not applicable.

Informed Consent Statement: Not applicable.

Data Availability Statement: Data is contained within the article.

Conflicts of Interest: The authors declare no conflict of interest.

\section{References}

1. Kalak, T.; Cierpiszewski, R.; Ulewicz, M. High Efficiency of the Removal Process of $\mathrm{Pb}(\mathrm{II})$ and $\mathrm{Cu}(\mathrm{II})$ Ions with the Use of Fly Ash from Incineration of Sunflower and Wood Waste Using the CFBC Technology. Energies 2021, 14, 1771. [CrossRef]

2. Erdoğan, S.; Önal, Y.; Akmil-Başar, C.; Bilmez-Erdemoğlu, S.; Sarıcı-Özdemir, Ç.; Köseoğlu, E.; İçduygu, G. Optimization of nickel adsorption from aqueous solution by using activated carbon prepared from waste apricot by chemical activation. Appl. Surf. Sci. 2005, 252, 1324-1331. [CrossRef]

3. Demirbaş, E.; Kobya, M.; Öncel, S.; Şencan, S. Removal of Ni(II) from aqueous solution by adsorptiononto hazelnut shell activated carbon: Equilibrium studies. Bioresour. Technol. 2002, 84, 291-293. [CrossRef]

4. Raji, M.; Ibrahim, Y.; Ehinmidu, J. Physico-chemical characteristics and Heavy metal levels in Drinking Water sources in Sokoto metropolis in North-western Nigeria. J. Appl. Sci. Environ. Manag. 2010, 14, 81-85. [CrossRef]

5. Gautam, P.K.; Gautam, R.K.; Banerjee, S.; Chattopadhyaya, M.C.; Pandey, J.D. Heavy metals in the environment: Fate, transport, toxicity and remediation technologies. Heavy Met. 2016, 4, 1-29.

6. Bhalerao, S.A.; Sharma, A.S.; Poojari, A.C. Toxicity of Nickel in Plants. Int. J. Pure App. Biosci. 2015, 3, 345-355.

7. Tchounwou, P.B.; Yedjou, C.G.; Patlolla, A.K.; Sutton, D.J. Heavy metal toxicity and the environment. Exp. Suppl. 2012, 101, 133-164. [PubMed]

8. Maarof, H.; Daud, W.; Aroua, M. Recent trends in removal and recovery of heavy metals from wastewater by electrochemical technologies. Rev. Chem. Eng. 2017, 33, 359-386. [CrossRef] 
9. Bazrafshan, E.; Mohammadi, L.; Ansari-Moghaddam, A.; Mahvi, A.H. Heavy metals removal from aqueous environments by electrocoagulation process-A systematic review. J. Environ. Health Sci. Eng. 2015, 13, 1-16. [CrossRef] [PubMed]

10. Park, J.-H.; Eom, J.-H.; Lee, S.-L.; Hwang, S.-W.; Kim, S.-H.; Kang, S.-W.; Yun, J.-J.; Cho, J.-S.; Lee, Y.-H.; Seo, D.-C. Exploration of the potential capacity of fly ash and bottom ash derived from wood pellet-based thermal power plant for heavy metal removal. Sci. Total Environ. 2020, 740, 140205. [CrossRef]

11. Qiu, R.; Cheng, F.; Huang, H. Removal of $\mathrm{Cd}^{2+}$ from aqueous solution using hydrothermally modified circulating fluidized bed fly ash resulting from coal gangue power plant. J. Clean. Prod. 2018, 172, 1918-1927. [CrossRef]

12. Ahmaruzzaman, M. Industrial wastes as low-cost potential adsorbents for the treatment of wastewater laden with heavy metals. Adv. Colloid Interface Sci. 2011, 166, 36-59. [CrossRef]

13. Kalak, T.; Kłopotek, A.; Cierpiszewski, R. Effective adsorption of lead ions using fly ash obtained in the novel circulating fluidized bed combustion technology. Microchem. J. 2019, 145, 1011-1025.

14. Kalak, T.; Cierpiszewski, R. Comparative studies on the adsorption of $\mathrm{Pb}(\mathrm{II})$ ions by fly ash and slag obtained from $\mathrm{CFBC}$ technology. Pol. J. Chem. Technol. 2019, 21, 72-81. [CrossRef]

15. Fytili, D.; Zabaniotou, A. Utilization of sewage sludge in EU application of old and new methods-A review. Renew. Sustain. Energy Rev. 2008, 12, 116-140. [CrossRef]

16. Kalisz, M. Prognozy zmian w gospodarce osadami ściekowymi. Wodociagi Kanalizacja 2007, 3, 30-31.

17. Ahmaruzzaman, M. A review on the utilization of fly ash. Prog. Energy Combust. Sci. 2010, 36, 327-363. [CrossRef]

18. Malik, A.; Thapliyal, A. Eco-friendly Fly Ash Utilization: Potential for Land Application. Crit. Rev. Environ. Sci. Technol. 2009, 39, 333-366. [CrossRef]

19. European Environment Agency. Large Combustion Plants Operating in Europe. Available online: https:/ / www.eea.europa.eu/ data-and-maps/indicators/large-combustion-plants-operating-in-europe-3/assessment (accessed on 17 April 2021).

20. Wójtowicz, A. Kierunki zagospodarowania komunalnych osadów ściekowych w świetle zmian prawa. In Proceedings of the Conference-Urząd Marszałkowski Województwa Pomorskiego, Gdańsk, Poland, 11 May 2012.

21. Werle, S.; Dudziak, M. Gasification of sewage sludge. In Industrial and Municipal Sludge; Industrial and Municipal Sludge: Oxford, UK, 2019; pp. 575-593.

22. Eurostat. Sewage Sludge Production and Disposal. Available online: http://appsso.eurostat.ec.europa.eu/nui/show.do?dataset= env_Ww_spd\&lang=en (accessed on 17 April 2021).

23. Shim, Y.-S.; Kim, Y.-K.; Kong, S.-H.; Rhee, S.-W.; Lee, W.-K. The adsorption characteristics of heavy metals by various particle sizes of MSWI bottom ash. Waste Manag. 2003, 23, 851-857. [CrossRef]

24. Police, S.; Maity, S.; Chaudhary, D.K.; Dusane, C.K.; Sahu, S.K.; Kumar, A.V. Effect of coal fly ash's particle size on U adsorption in water samples and thermodynamic study on adsorption. Environ. Chem. Ecotoxicol. 2020, 2, 32-38. [CrossRef]

25. Itskos, G.; Koukouzas, N.; Vasilatos, C.; Megremi, I.; Moutsatsou, A. Comparative uptake study of toxic elements from aqueous media by the different particle-size-fractions of fly ash. J. Hazard. Mater. 2010, 183, 787-792. [CrossRef]

26. Lanzerstorfer, C. Fly ash from coal combustion: Dependence of the concentration of various elements on the particle size. Fuel 2018, 228, 263-271. [CrossRef]

27. Kara, S.; Aydiner, C.; Demirbas, E.; Kobya, M.; Dizge, N. Modeling the effects of adsorbent dose and particle size on the adsorption of reactive textile dyes by fly ash. Desalination 2007, 212, 282-293. [CrossRef]

28. Feng, S.; Li, Y. Study on coal fly ash classified by bulk density. J. Phys. Conf. Ser. 2021, 1732, 012127. [CrossRef]

29. Nawaz, I. Disposal and Utilization of Fly Ash to Protectthe Environment. Int. J. Innov. Res. Sci. Eng. Technol. 2013, 2, 5259-5266.

30. Mahieux, P.-Y.; Aubert, J.-E.; Cyr, M.; Coutand, M.; Husson, B. Quantitative mineralogical composition of complex mineral wastes-Contribution of the Rietveld method. Waste Manag. 2009, 30, 378-388. [CrossRef] [PubMed]

31. Coutand, M.; Cyr, M.; Clastres, P. Use of sewage sludge ash as mineral admixture in mortars. Proceedings of the Institution of Civil Engineers. Constr. Mater. 2006, 159, 153-162. [CrossRef]

32. Zhou, Y.-F.; Li, J.-S.; Lu, J.-X.; Cheeseman, C.; Poon, C.S. Sewage sludge ash: A comparative evaluation with fly ash for potential use as lime-pozzolan binders. Constr. Build. Mater. 2020, 242, 118160. [CrossRef]

33. Li, H.L.; Liu, G.L.; Cao, Y. Content and Distribution of Trace Elements and Polycyclic Aromatic Hydrocarbons in Fly Ash from a Coal-Fired CHP Plant. Aerosol Air Qual. Res. 2014, 14, 1179-1188. [CrossRef]

34. Xiong, L.; Wan, Z.; Zhang, Y.; Wang, F.; Wang, J.; Kang, Y. Fly Ash Particle Size Effect on Pore Structure and Strength of Fly Ash Foamed Geopolymer. Adv. Polym. Technol. 2019, 1098027, 1-10. [CrossRef]

35. Dos Santos, R.P.; Martins, J.; Gadelha, C.; Cavada, B.; Albertini, A.V.; Arruda, F.; Vasconcelos, M.; Teixeira, E.; Alves, F.; Lima Filho, J.; et al. Coal fly ash ceramics: Preparation, characterization, and use in the hydrolysis of sucrose. Sci. World J. 2014, 154651, 1-7. [CrossRef]

36. Paya, J.; Monzo, J.; Borrachero, M.V.; Perris, E.; Amahjour, F. Thermogravimetric methods for determinig carbon content in fly ashes. Cem. Concr. Res. 1998, 28, 675-686. [CrossRef]

37. Khan, A.A.; de Jong, W.; Jansens, P.J.; Spliethoff, H. Biomass combustion in fluidized bed boilers: Potential problems and remedies. Fuel Process. Technol. 2009, 90, 21-50. [CrossRef]

38. Yue, Y.; Wang, J.J.; Basheer, P.; Bai, Y. Establishing the Carbonation Profile with Raman Spectroscopy: Effects of Fly Ash and Ground Granulated Blast Furnace Slag. Materials 2021, 14, 1798. [CrossRef] [PubMed] 
39. Du, B.; Li, J.; Fang, W.; Liu, Y.; Yu, S.; Li, Y.; Liu, J. Characterization of naturally aged cement-solidified MSWI fly ash. Waste Manag. 2018, 80, 101-111. [CrossRef]

40. Villain, G.; Thiery, M.; Platret, G. Measurement methods of carbonation profiles in concrete: Thermogravimetry, chemical analysis and gammadensimetry. Cem. Concr. Res. 2007, 37, 1182-1192. [CrossRef]

41. Magdziarz, A.; Werle, S. Analysis of the combustion and pyrolysis of dried sewage sludge by TGA and MS. Waste Manag. 2014, 34, 174-179. [CrossRef]

42. Liu, X.; Mäki-Arvela, P.; Aho, A.; Vajglova, Z.; Gun'ko, V.M.; Heinmaa, I.; Kumar, N.; Eränen, K.; Salmi, T.; Murzin, D.Y. Zeta Potential of Beta Zeolites: Influence of Structure, Acidity, pH, Temperature and Concentration. Molecules 2018, 23, 946. [CrossRef]

43. Liberto, T.; Barentin, C.; Colombani, J.; Costa, A.; Gardini, D.; Bellotto, M.; Le Merrer, M. Simple ions control the elasticity of calcite gels via interparticle forces. J. Colloid Inter. Sci. 2019, 553, 280-288. [CrossRef]

44. Hadadian, Y.; Ramos, A.P.; Pavan, T.Z. Role of zinc substitution in magnetic hyperthermia properties of magnetite nanoparticles: Interplay between intrinsic properties and dipolar interactions. Sci. Rep. 2019, 9, 18048. [CrossRef]

45. Dedecek, J.; Balgová, V.; Pashkova, V.; Klein, P.; Wichterlová, B. Synthesis of ZSM-5 Zeolites with Defined Distribution of Al Atoms in the Framework and Multinuclear MAS NMR Analysis of the Control of Al Distribution. Chem. Mater. 2012, 24, 3231-3239. [CrossRef]

46. Hensen, E.J.M.; Poduval, D.G.; Ligthart, D.A.J.M.; van Veen, J.A.R.; Rigutto, M.S. Quantification of Strong Brønsted Acid Sites in Aluminosilicates. J. Phys. Chem. C 2010, 114, 8363-8374. [CrossRef]

47. Ronson, T.O.; Carney, J.R.; Whitwood, A.C.; Taylor, R.J.K.; Fairlamb, I.J.S. AsCat and FurCat: New Pd catalysts for selective room-temperature Stille cross-couplings of benzyl chlorides with organostannanes. Chem. Commun. 2015, 51, 3466-3469. [CrossRef]

48. Kong, D.L.Y.; Sanjayan, J.G.; Sagoe-Crentsil, K. Comparative performance of geopolymers made with metakaolin and fly ash after exposure to elevated temperatures. Cem. Concr. Res. 2007, 37, 1583-1589. [CrossRef]

49. Hardjito, D.; Wallah, S.E.; Sumajouw, D.M.J.; Rangan, B.V. Fly ash-based geopolymer concrete. Aust. J. Struct. Eng. 2005, 6, 77-86. [CrossRef]

50. Alinnor, I.J. Adsorption of heavy metal ions from aqueous solution by fly ash. Fuel 2007, 86, 853-857. [CrossRef]

51. Temuujin, J.; Riessen, A.V. Effect of fly ash preliminary calcination on the properties of geopolymer. J. Hazard. Mater. 2009, 164, 634-639. [CrossRef]

52. Mustafa, A.M.; Kamarudin, H.; Omar Karem, A.K.A.; Ruzaidi, C.M.; Rafiza, A.R.; Norazian, M.N. Optimization of Alkaline Activator/Fly Ash Ratio on The Compressive Strength of Manufacturing Fly Ash-Based Geopolymer. Appl. Mech. Mater. 2011, 110-116, 734-739.

53. Thokchom, S.; Ghosh, P.; Ghosh, S. Resistance of Fly Ash Based Geopolymer Mortars in Sulfuric Acid. ARPN J. Eng. Appl. Sci. 2009, 4, 65-70.

54. Bansal, R.C.; Goyal, M. Activated Carbon Adsorption; CRC Press, Taylor and Francis Group, LLC: Boca Raton, FL, USA, 2005.

55. Magdziarz, A.; Kosowska-Golachowska, M.; Kijo-Kleczkowska, A.; Musiał, T.; Środa, K.; Wolski, K.; Richter, D. Analysis of sewage sludge ashes from air and oxy-fuel combustion in a circulating fluidized-bed. In Proceedings of the 1st International Conference on the Sustainable Energy and Environment Development (SEED 2016), Krakow, Poland, 14-17 November 2017; Volume 10, p. 00054.

56. Gao, N.; Kamran, K.; Quan, C.; Williams, P.T. Thermochemical conversion of sewage sludge: A critical review. Prog. Energy Combust. Sci. 2020, 79, 100843. [CrossRef]

57. Gao, J.; Wang, T.; Zhao, J.; Hu, X.; Dong, C. An Experimental Study on the Melting Solidification of Municipal Solid Waste Incineration Fly Ash. Sustainability 2021, 13, 535. [CrossRef]

58. Chen, C.-H.; Chiou, I.-J.; Wang, K.-S. Sintering effect on cement bonded sewage sludge ash. Cem. Concr. Compos. 2006, 28, 26-32. [CrossRef]

59. Cui, X.; Fang, S.; Yao, Y.; Li, T.; Ni, Q.; Yang, X.; He, Z. Potential mechanisms of cadmium removal from aqueous solution by Canna indica derived biochar. Sci. Total Environ. 2016, 562, 517-525. [CrossRef]

60. Erdemoğlu, M.; Sarikaya, M. Effects of heavy metals and oxalate on the zeta potential of magnetite. J. Colloid Interf. Sci. 2006, 300, 795-804. [CrossRef] [PubMed]

61. Huang, L.-F.; Hutchison, M.J.; Santucci, R.J., Jr.; Scully, J.R.; Rondinelli, J.M. Improved Electrochemical Phase Diagrams from Theory and Experiment: The Ni-Water System and Its Complex Compounds. J. Phys. Chem. C 2017, 121, 9782-9789. [CrossRef]

62. Mînzatu, V.; Davidescu, C.-M.; Negrea, P.; Ciopec, M.; Muntean, C.; Hulka, I.; Paul, C.; Negrea, A.; Duteanu, N. Synthesis, Characterization and Adsorptive Performances of a Composite Material Based on Carbon and Iron Oxide Particles. Int. J. Mol. Sci. 2019, 20, 1609. [CrossRef]

63. Langeroodi, N.S.; Farhadravesh, Z.; Khalaji, A.D. Optimization of adsorption parameters for Fe (III) ions removal from aqueous solutions by transition metal oxide nanocomposite. Green Chem. Lett. Rev. 2018, 11, 404-413. [CrossRef]

64. Onundi, Y.B.; Mamun, A.A.; Khatib, M.F.A.; Al Saadi, M.A.; Suleyman, A.M. Heavy metals removal from synthetic wastewater by a novel nano-size composite adsorbent. Int. J. Environ. Sci. Technol. 2011, 8, 799-806. [CrossRef]

65. Zamani, S.; Salahi, E.; Mobasherpour, I. Removal of Nickel from Aqueous Solution by Nano Hydroxyapatite Originated from Persian Gulf Corals. Can. Chem. Trans. 2013, 1, 173-190. 
66. Ren, Y.; Yan, N.; Wen, Q.; Fan, Z.; Wei, T.; Zhang, M.; Ma, J. Graphene/ $\delta-\mathrm{MnO}_{2}$ composite as adsorbent for the removal of nickel ions from wastewater. Chem. Eng. J. 2011, 175, 1-7. [CrossRef]

67. Liew, Y.M.; Heah, C.Y.; Kamarudin, H. Structure and properties of clay-based geopolymer cements: A review. Prog. Mater. Sci. 2016, 83, 595-629. [CrossRef]

68. Mobasherpour, I.; Salahi, E.; Ebrahimi, M. Removal of divalent nickel cations from aqueous solution by multi-walled carbon nano tubes: Equilibrium and kinetic processes. Res. Chem. Intermed. 2012, 38, 2205-2222. [CrossRef]

69. Chen, X.; Guo, Y.; Ding, S.; Zhang, H.; Xia, F.; Wang, J.; Zhou, M. Utilization of red mud in geopolymer-based pervious concrete with the function of adsorption of heavy metal ions. J. Clean. Prod. 2019, 207, 789-800. [CrossRef]

70. Kara, I.; Tunc, D.; Sayin, F.; Akar, S.T. Study on the performance of metakaolin based geopolymer for Mn(II) and Co(II) removal Appl. Clay Sci. 2018, 161, 184-193. [CrossRef]

71. Mondal, M.; Dutta, M.; De, S. A novel ultrafiltration grade nickel iron oxide doped hollow fiber mixed matrix membrane: Spinning, characterization and application in heavy metal removal. Sep. Purif. Technol. 2017, 188, 155-166. [CrossRef]

72. Zhang, Y.; Liu, Y.; Wang, X.; Sun, Z.; Ma, J.; Wu, T.; Xing, F.; Gao, J. Porous graphene oxide/carboxymethyl cellulose monoliths, with high metal ion adsorption. Carbohydr. Polym. 2014, 101, 392-400. [CrossRef] [PubMed]

73. Rahmani, A.; Zavvar Mousavi, H.; Fazli, M. Effect of nanostructure alumina on adsorption of heavy metals. Desalination 2010, 253, 94-100. [CrossRef]

74. Zhou, Z.; Kong, D.; Zhu, H.; Wang, N.; Wang, Z.; Wang, Q.; Liu, W.; Li, Q.; Zhang, W.; Zhongqi Ren, Z. Preparation and adsorption characteristics of an ion-imprinted polymer for fast removal of $\mathrm{Ni}$ (II) ions from aqueous solution. J. Hazard. Mater. 2018, 341, 355-364. [CrossRef] [PubMed]

75. Li, P.; Liu, C.; Zhang, L.; Zheng, S.; Zhang, Y. Enhanced boron adsorption onto synthesized MgO nanosheets by ultrasonic method. Ultrason. Sonochem. 2017, 34, 938-946. [CrossRef]

76. El-Bahy, S.M.; El-Bahy, Z.M. Synthesis and characterization of polyamidoxime chelating resin for adsorption of Cu(II), Mn(II) and $\mathrm{Ni}(\mathrm{II})$ by batch and column study. J. Environ. Chem. Eng. 2016, 4, 276-286. [CrossRef]

77. Shirkhanloo, H.; Khaligh, A.; Mousavi, H.Z.; Rashidi, A. Graphene oxide-packed micro-column solid-phase extraction combined with flame atomic absorption spectrometry for determination of lead (II) and nickel (II) in water samples. Int. J. Environ. Anal. Chem. 2015, 95, 16-32. [CrossRef]

78. Zare-Dorabei, R.; Ferdowsi, S.M.; Barzin, A.; Tadjarodi, A. Highly efficient simultaneous ultrasonic-assisted adsorption of Pb(II), $\mathrm{Cd}(\mathrm{II}), \mathrm{Ni}(\mathrm{II})$ and $\mathrm{Cu}$ (II) ions from aqueous solutions by graphene oxide modified with 2,2'-dipyridylamine: Central composite design optimization. Ultrason. Sonochem. 2016, 32, 265-276. [CrossRef]

79. Bai, Z.; Zheng, Y.; Zhang, Z. One-pot synthesis of highly efficient MgO for the removal of Congo red in aqueous solution. J. Mater. Chem. A 2017, 5, 6630-6637. [CrossRef]

80. Mužek, M.N.; Svilović, S.; Zelić, J. Kinetic studies of cobalt ion removal from aqueous solutions using fly ash-based geopolymer and zeolite NaX as sorbents. Sep. Sci. Technol. 2016, 51, 2868-2875. [CrossRef]

81. Wang, H.; Wang, W.; Zhao, Y.; Xu, Z.; Chen, L.; Zhao, L.; Tian, X.; Sun, W. Superior Adsorption of 3D Nanoporous Architectures for Ni(II) Ions Adsorption Using Polyvinyl Alcohol as Cross-Linking Agent and Adsorption Conveyor. RSC Adv. 2018, 8, 7899-7903. [CrossRef]

82. Panda, L.; Rath, S.S.; Rao, D.S.; Nayak, B.B.; Das, B.; Misra, P.K. Thorough understanding of the kinetics and mechanism of heavy metal adsorption onto a pyrophyllite mine waste-based geopolymer. J. Mol. Liq. 2018, 263, 428-441. [CrossRef]

83. Ghani, U.; Hussain, S.; Noor-ul-Amin; Imtiaz, M.; Khan, S. Laterite clay-based geopolymer as a potential adsorbent for the heavy metals removal from aqueous solutions. J. Saudi Chem. Soc. 2020, 24, 874-884. [CrossRef]

84. Kalembkiewicz, J.; Galas, D.; Sitarz-Palczak, E. The Physicochemical Properties and Composition of Biomass Ash and Evaluating Directions of its Applications. Pol. J. Environ. Stud. 2018, 27, 2593-2603. [CrossRef] 